\title{
Rintamakirjeissä rakentuva sodan maisema
}

\author{
Sonja Hagelstam
}

\section{Abstrakti}

Jatkosota 1941-1944 vei suomalaiset sotilaat kauaksi itään - alueille, jotka monin tavoin erosivat kotiseudun totutusta ympäristöstä. Artikkeli käsittelee sotilaiden kokemuksia maisemasta, sitä mitä ajatuksia ja tunteita se heissä herätti ja kuinka he arjen käytännöissään ottivat vieraan maiseman haltuunsa ja muunsivat sen "omaksi".

Artikkelin aineisto koostuu viiden sotilaan jatkosodan aikana kirjoitetuista rintamakirjeistä. Mitä kirjeet kotiin kertovat sotilaiden ja maiseman välisestä vuorovaikutuksesta? Millaiseksi maisema rakentui sotilaiden läheisilleen kirjoittamissaan kirjeissä? Miten he kokivat maiseman ja mitä tunteita se heissä herätti? Miten he ottivat vieraan maiseman haltuunsa?

Sotilaille sodan ja rintaman maisema oli monin tavoin ristiriitainen. Jatkosodan aikana sotilaat kohtasivat sodan tuhoaman, runteleman ja vääristämän maiseman, toisaalta "bolševikkiparatiisin" primitiivisyyden ja toisaalta taas Itä-Karjalan koskemattoman ja kauniin luonnonmaiseman. Kirjeissään sotilaat kuvailivat havaitsemaansa, ja pukemalla näkemäänsä sanoiksi rakentui niissä kuvia maisemasta - kuvia, jotka sotilaat eri syistä halusivat jakaa läheistensä kanssa. Kotiväkeä ei haluttu turhaan huolestuttaa tai järkyttää, mikä osin selittää, miksi kirjeet eivät yleensä sisältäneet yksityiskohtaisia kuvauksia rintamasta kuoleman tai tuhon maisemana. Artikkelissa osoitan, miten sotilaat kirjeissään rakensivat kuvia rintamamaisemasta, jossa oli useita yhtymäkohtia kotiseutuun. Vaikka sotilaat eivät täysin vaienneet väkivallan merkeistä maisemassa tai kaikesta, mikä tuntui vieraalta ja oudolta, painopiste oli kuitenkin turvallisuutta ja jatkuvuutta ylläpitävissä aiheissa. 
uonto on kyllä hieno avarine näkymine yli suurten vetten ja sinertävien kukkuloiden, mutta voi hyvä jumala miten ruma ja roskainen maisema on. On mahdotonta sanoin kuvata kuinka kaikki täällä näyttää sotkuiselta. Laudanpätkiä, lasinsiruja, paperia, lumppuja, rojua ja ylipäänsä kaikkea maan ja taivaan väliltä [...] peittää kaiken paksuin kerroksin. Jopa metsät näyttävät likaisilta. Talot, myös kaupungissa olevat, ovat muutamia komeilevia poikkeuksia lukuun ottamatta joukko röttelöitä. Huomaa selvästi, että mitään ei ole tehty niiden kunnossapitämiseksi ainakaan 25 vuoteen. Perustukset ovat painuneet, seinät vinoja, puolet ikkunoista on korvattu rääsyillä ja laudanpätkillä, katot ovat ränsistyneet tai välttävästi paikattu millä ikinä on satuttu saamaan käsiin. Ja joka puolella likaa, likaa paksuina kerroksina. (Eversti Sven Björkman vaimolleen 3.10.1941.)

Näin kuvaili eversti Sven Björkman maisemaa Petroskoissa ja kaupungin lähiympäristössä pari päivää kaupungin valtauksen jälkeen syksyllä 1941. Rintamalla miehille avautui totutusta poikkeava maailma uusine kokemuksineen ja vaikutelmineen. Maisema, jonka eversti kohtasi, herätti hänessä ihmetystä. Samalla maiseman epäsiisteys ja pahasti ränsistyneet rakennukset olivat silminnähtäviä todisteita neuvostoliittolaisen yhteiskuntajärjestelmän täydellisestä epäonnistumisesta.

Jatkosota 1941-1944 vei suomalaiset rintamalla palvelevat kauaksi itään - alueille, jotka monin tavoin erosivat kotiseudun totutusta ympäristöstä. Tutkin viiden sotilaan tapaa kirjoittaa maisemasta, jonka he kohtasivat rintamalla ja jossa he elivät kuukausien ja vuosien ajan. Millaiseksi maisema rakentui sotilaiden läheisilleen kirjoittamissa kirjeissä? Miten he kokivat maiseman ja mitä tunteita se heissä herätti? Mitä kirjeet kertovat sotilaiden ja maiseman välisestä vuorovaikutuksesta? Miten he ottivat vieraan maiseman haltuunsa ja muovasivat sen omaksi? En näe rintaman luontoa, ympäristöä tai maisemaa passiivisena taustana sodankäynnille vaan aktiivisena toimijana, joka vaati sotilailta erityisiä taitoja ja toimintatapoja, mutta joka myös herätti heissä tunteita ja ajatuksia. Miten sodan maisema vaikutti sotilaisiin ja mitä he tekivät maisemalle arjessaan ja ajatuksissaan?

Sodan maisema on artikkelissani hyvin laaja käsite, jolla tarkoitan sotilaiden rintamalla kohtaamaa ja kokemaa luontoa, ympäristöä, maastoa ja näiden eri ulottuvuuksia. Lähestyn maisemaa tulkittuna ja konstruoituna ilmiönä, joka syntyy, kun ihminen havainnoi ympäristöään, liikkuu ja toimii siinä sekä pukee näkemäänsä ja kokemaansa sanoiksi (vrt. Häyrynen 2004, 56-57). Tulkintaa ja analyysiä inspiroineita teoreettisia näkökulmia tuodaan esille artikkelin analyysiluvuissa. Ranskalaisten teoreetikkojen Gilles Deleuzen ja Félix Guattarin (2004) ajattelu sommitelmista ja rihmastoista on toiminut taustalla olevana inspiraationa näkemykseeni rintamasta tilana ja sen rakentumisesta rintaman ja kotirintaman välisissä kirjeenvaihdoissa. Kytkemällä yhteen erilaisia elementtejä tilassa - sodan elementtejä, luonnon elementtejä, "siviilejä" elementtejä - kirjeenkirjoittajat loivat kokonaisuuksia tai kuvia sodan maisemasta (Hagelstam 2014).

Teoksissa, joissa käsitellään sotilaiden kokemuksia sodasta, heitä ympäröivä maisema on usein läsnä, mutta se ei yleensä ole ollut tarkastelun keskiössä (esim. Holmes 2004; Fritz 1995). Viime vuosina kiinnostus maiseman, paikan ja ympäristön merkityksiin sodassa, kriiseissä ja eri sotilaallisissa konteksteissa on kasvanut (esim. Woodward 2004; Helphand 2006). Painottamalla yksittäisten sotilaiden kokemuksia, ajatuksia ja tunteita maisemasta rintamalla artikkelini syventää tietämystä maiseman merkityksestä sotilaiden kokemuksissa sodasta ja antaa näin uuden näkökulman sodan kokemushistoriaan. Artikkelissa osoitan muun muassa, kuinka sotilaat kirjeissään läheisilleen rakensivat kuvia rintamamaisemasta, jossa oli useita yhtymäkohtia kotiseutuun. Vaikka artikkelin sotilaat eivät täysin vaienneet 
väkivallan merkeistä maisemassa tai kaikesta, mikä tuntui vieraalta ja oudolta, painopiste oli kuitenkin turvallisuutta ja jatkuvuutta ylläpitävissä aiheissa.

Aineiston lyhyen esittelyn jälkeen käsittelen sotilaiden tapaa nähdä ja kokea idässä kohtaamaansa, heille vierasta maisemaa. Tämän jälkeen analysoin, miten sotilaat kirjoittivat sodan tuhoamasta rintamamaisemasta ja miten he kokivat vaativat ja usein uuvuttavat olosuhteet, joissa vuosien ajan joutuivat elämään. Lopuksi tutkin, miten sotilaat eri keinoin ottivat vieraan ja vaarallisen maiseman haltuunsa luoden siitä "tutun" ja "turvallisen" ympäristön.

\section{Sotilaat ja kirjeet}

Artikkelin lähdeaineisto koostuu neljästä laajasta kirjekokoelmasta, jotka on tallennettu Åbo Akademin kirjaston käsikirjoitusosastolle.' Kaikki kokoelmat sisältävät kirjeitä sekä rintamalta kotiin että kotoa rintamalle, mutta tässä artikkelissa keskitytään pääasiassa rintamalta kotiin lähetettyihin kirjeisiin. Kahdessa kokoelmassa kirjeenvaihtoa kävivät rintamalla oleva poika ja hänen vanhempansa, kahdessa aviomies ja aviovaimo. Yksi kokoelma sisältää kirjeitä kahdelta pojalta vanhemmilleen, ja siksi artikkelissa käsitellään viiden sotilaan kokemuksia. Aineistoni sotilailla on eri sotilasarvot (eversti, luutnantti, ylikersantti, alikersantti ja sotamies), he edustavat eri aselajeja ja olivat sijoitettuina eri rintamalohkoille. Muun muassa nämä seikat vaikuttivat miesten henkilökohtaisiin kokemuksiin rintamalla ja näin myös kirjeiden sisältöihin.

Eversti Sven Björkman (1898-1981) oli panssaripataljoonan komentaja, ja vuodesta 1942 panssariprikaatin komentaja. Panssarijoukot osallistuivat vuonna 1941 taisteluihin Aunuksen kannaksella ja Maaselässä ja olivat asemasodan aikana sijoitettuna Äänislinnaan eli Petroskoihin. Kesällä 1944 panssarijoukot osallistuivat puolustustaisteluihin Karjalankannaksella. Sven Björkman ja hänen vaimonsa Rakel (1899-1979) olivat menneet naimisiin 1926 ja heillä oli kaksi tytärtä. Molemmat olivat alun perin kotoisin Helsingistä, mutta Sven Björkmanin sotilasura vei heidät vuosien aikana eri paikkakunnille. Pariskunta oli muun muassa 1920-luvulla asunut Viipurissa ja jatkosodan aikana perheellä oli koti Suomen kasarmilla Hämeenlinnassa. Björkmanien kokoelman 646 kirjeestä 345 on everstin kirjoittamia.

Porvoosta kotoisin oleva taideopiskelija ja luutnantti Ulf Segerstråle (1916-1944) oli taiteilijaperheen vanhin lapsi. Hän toimi jatkosodassa ruotsinkielisessä jalkaväkirykmentti 24:ssä joukkueenjohtajana, mutta myös urheilu-upseerina ja valistusupseerina. Hän kaatui suomalaisten joukkojen vetäytyessä Suurmäessä 29.6.1944. Segerstrålen kirjekokoelma koostuu Ulfin kirjeistä vanhemmilleen ja kahdelle sisarelleen sekä kaikilta heiltä hänelle. Kokoelma käsittää noin 900 kirjettä, joista 346 on Ulf Segerstrålen kirjoittamia.

1 Sota-ajan kirjeitä on 1960-1970-luvuilta lähtien kerätty Åbo Akademin kirjaston käsikirjoitusosaston lisäksi mm. Tampereen yliopiston Kansanperinteen arkistoon. Aineistoja ei kuitenkaan moneen vuoteen juurikaan käytetty tutkimuksessa. Osittain tämä selittyy sillä, että sotakirjeitä pidettiin lähdekriittisestä näkökulmasta ongelmallisina postisensuurin takia. Perinteisessä sotahistorian tutkimuksessa, jossa pääasiassa tarkasteltiin makrotason ilmiöitä, ei yksityisten inmisten kokemuksia sodasta pidetty kiinnostavina tai relevantteina. Sota-ajan kirjeiden käyttö tutkimuksessa on kuitenkin yleistynyt parin viime vuosikymmenen aikana huomattavasti. Sotakirjeitä on käytetty pääasiallisina lähteinä useissa pro gradu -tutkielmissa ja myös kahdessa etnologian alan väitöskirjassa (Pehkonen 2013; Hagelstam 2014), Kirjeitä sodista ja kriiseistä on käsitelty myös kokoomateoksessa Kirjeitä sodasta (2015) sekä Tampereen yliopiston verkkojulkaisussa Arjen sirpaleita ja suuria tunteita (2017). 
Porvoon maalaiskunnassa syntynyt kansakoulunopettaja Curt Enroth (1912-1988) ja Martha (1894-1974) olivat menneet naimisiin 1938, mutta pariskunnalla ei ollut lapsia. Jatkosodan aikana ylikersantti Enroth oli sijoitettuna tykistöön, Raskaaseen patteristoon 21, jossa hän toimi jaoksen johtajana ja talousaliupseerina. Kotiuttamisen jälkeen hän jatkoi opettajantyötään Sipoossa, jossa hän vuodesta 1935 lähtien oli toiminut Kallbäckin kylän kansakoulun ainoana opettajana. Kokoelma sisältää 1414 kirjettä, joista 794 on miehen kirjoittamia.

Curt Enrothin ja Ulf Segerstrålen joukko-osastot kuuluivat 8. Divisioonaan ja tästä syystä he liikkuivat koko sodan samoilla alueilla. Hyökkäysvaiheen aikana JR 24 ja Rask.psto 21 osallistuivat taisteluihin Karjalankannaksella ja Maaselässä. Asemasodan ajan ne olivat sijoitettuna Syvärin tienoille ja kesällä 1944 osallistuivat torjuntataisteluihin Aunuksen kannaksella.

Veljekset Nils ja Göran Sax olivat pohjanmaalaisen maanviljelijäperheen kaksi vanhinta poikaa. Alikersantti Nils Sax (1920-2004) toimi ryhmänjohtajana ja myöhemmin lähettialiupseerina suomenkielisessä jalkaväkirykmentti 6:ssa, joka oli koko jatkosodan ajan sijoitettuna Karjalankannakselle. Nils oli ylioppilas ja haki jo sodan aikana Helsingin yliopistoon, jossa hän sodan jälkeen suoritti opintonsa loppuun. Vuonna 1957 hän muutti vaimonsa kanssa Ruotsiin, jossa eli loppuelämänsä. Sotamies Göran Sax (1922-2003) toimi ajomiehenä ruotsinkielisessä jalkaväkirykmentti 61:ssä toisen pataljoonan kranaatinheitinjoukkueessa. Lyhyen sotilaskoulutuksen jälkeen hän saapui rintamalle vuoden 1942 alussa. JR 61 oli sijoitettuna Syvärille, mutta kesäkuussa 1944 se siirrettiin pikaisesti Karjalankannakselle. Sodan jälkeen Göran Sax meni naimisiin ja jatkoi isänsä jalanjäljissä maanviljelijänä. Tämä kokoelma koostuu 692 kirjeestä, joista 252 on Nilsin ja 295 Göranin vanhemmilleen kirjoittamia. Kokoelmaan kuuluu myös 24 kirjettä Nilsiltä Göranille sekä vanhempien lähettämät kirjeet Göranille.

Kun sota syttyi kesäkuun lopulla 1941 ja miehet joutuivat rintamalle, kirjeenvaihdosta tuli pääasiallinen tapa pitää yllä yhteyttä kodin ja rintaman välillä. Kenttäposti organisoitiin, jotta yhteys siviiliväestön ja rintamasotilaiden välillä olisi mahdollista. Kirjeitä kirjoitettiinkin poikkeuksellisen paljon: arvion mukaan kenttäposti toimitti noin miljardi postilähetystä jatkosodan aikana. Puolustusvoimissa ymmärrettiin säännöllisen yhteydenpidon tärkeys. Kansaa kannustettiin kirjoittamaan, jotta mieliala säilyisi korkealla sekä rintamalla että kotirintamalla. Puolustusvoimissa oltiin kuitenkin tietoisia, että yhteys saattoi vaikuttaa myös päinvastaisesti: huono mieliala levisi äkkiä kirjeitse rintamien välillä. Tämän lisäksi haluttiin estää sellaisten tietojen leviäminen, joista olisi hyötyä viholliselle. Jokaisen keskuskenttäpostikonttorin yhteydessä oli sensuuritoimisto, jossa postia tarkastettiin. Vuoden 1941 kenttäpostioppaan mukaan oli ankarasti kiellettyä kirjoittaa joukkojen olinpaikasta tai minne ne mahdollisesti siirrettäisiin. Kiellettyä oli myös kirjoittaa joukko-osaston kunnosta, vahvuudesta tai aseistuksesta. Postisensuurin merkitystä ei kuitenkaan pidä liioitella. Koska kenttäpostin määrä oli niin valtaisa, tarkastukset suoritettiin pääosin pistokokein ja käytännössä vain hyvin pieni osa lähetyksistä avattiin. Aineistoni osoittaa, että sotilaat eivät eri syistä aina piitanneet säännöistä ja että kirjeet todellisuudessa sisältävät myös sellaista, mitä virallisten määräysten mukaan ei saanut mainita. Itsesensuurilla oli käytännössä paljon suurempi merkitys kirjeiden sisällön kannalta. Sotilaat eivät halunneet turhaan huolestuttaa läheisiään ja saattoivat sen takia vaieta kokemuksistaan tai vähätellä kokemaansa. (Ks. aiheesta enemmän Hagelstam 2011; Hagelstam \& Taskinen 2015.) 
Olen työstänyt aineistoani lähiluvun ja temaattisen analyysin keinoin. Lähiluvulla tarkoitan tarkkaa, systemaattista ja toistuvaa luentaa, jonka tavoitteena on saada kokonaiskuva aineistossa rakentuvasta maailmasta samalla, kun kiinnitetään huomiota rajatumpiin teemoihin ja yksityiskohtiin. (Pöysä 2015, 25-33.) Tähän prosessiin sisältyy myös syvää perehtymistä kirjeitä ympäröivään historialliseen, sosiaaliseen ja kulttuuriseen kontekstiin. Useat lukukerrat antavat syvällisen ja kokonaisvaltaisen tuntemuksen aineiston sisällöstä ja teemoista. Tässä artikkelissa olen keskittynyt sotarintaman erilaisiin tilallisiin ulottuvuuksiin ja siihen, miten nämä rakentuvat kirjeissä käydyn keskustelun puitteissa.

Artikkeli sisältää useita otteita kirjeistä. Mielestäni on tärkeää, että lukija pääsee osalliseksi kirjoittajien tavasta pukea kokemuksensa ja tunteensa sanoiksi. Kirjoittajat olivat kaikki ruotsinkielisiä ja kirjoittivat kirjeensä ruotsiksi. Olen kääntänyt otteet suomeksi, mikä ei välttämättä ole ollut aina helppoa tai ongelmatonta. Kirjeissä käytetty kieli on usein kirjoitetun ja puhutun kielen välimuoto, jota voi olla vaikea kääntää niin, että alkuperäinen sävy ja tyyli välittyvät myös suomeksi. Ne sisältävät myös kirjoittajien yksityiskieltä, murteellisia ilmaisuja, epätäydellisiä virkkeitä sekä kirjoitus- ja kieliopillisia virheitä, jotka myös voivat olla hankalia kääntää. Olen kuitenkin pyrkinyt tekemään käännökset niin, että kirjeiden alkuperäinen sisältö, tyyli ja sävy välittyisivät lukijalle.

\section{Vieraalla maalla}

Jatkosodan syttyessä kesäkuun lopulla 1941 asevelvolliset miehet joutuivat jättämään perheensä, kotinsa ja arkielämänsä, kun heidät siirrettiin rintamalle uuteen ja tuntemattomaan ympäristöön. He siirtyivät alueille, jotka monin tavoin erosivat tutusta maisemasta kotiseudulla. Siirtyminen tutusta tuntemattomaan toimi näin ollen tilallisena ja kulttuurisena murroskohtana miesten ja heidän perheidensä arjessa.

Vieraalla maalla liikkuvat sotilaat pohtivat usein kohtaamaansa ja vertailevat näkemäänsä omaan maahansa ja kotiseutuunsa (Fritz 1995, 123-134). Artikkelin sotilaat kirjoittivat maisemasta, luonnosta ja ympäristöstä Karjalassa ja Itä-Karjalassa erityisesti sodan alkupuolella, kun he ensimmäistä kertaa kohtasivat vieraan maiseman, mutta kuvauksia tai mainintoja löytyy kirjeistä myöhemminkin. Aluksi suomalaiset sotilaat liikkuivat alueilla, jotka ennen talvisodan loppua olivat kuuluneet Suomelle. Takaisin vallatussa Karjalassa sodan tuhot näkyivät maisemassa. Talvi- ja jatkosodan hyökkäysvaiheet olivat vyöryneet yli Karjalan ja raunioittaneet maakunnan. Myös kuukaudet Neuvostoliiton alaisuudessa olivat ehtineet jättää jälkensä maisemaan. Suomalaiset asukkaat oli evakuoitu Suomen puolelle heti talvisodan jälkeen ja alueelle oli muuttanut venäläisiä, jotka Suomen hyökätessä kesällä 1941 olivat jättäneet alueen. (Hakamies 2012, 75-77; Hietanen 1990, 152-169.) Heinäkuussa 1941 eversti Sven Björkman kirjoitti vaimolleen automatkastaan halki takaisinvallatun Karjalan. Entinen kotimaa tuntui vieraalta, ankealta, ja autio, tuhottu maisema herätti hänessä alakuloisuutta ja haikeuden tunnetta:

En ole ikinä voinut kuvitellakaan, että maisema kilometri toisensa jälkeen voisi jättää niin kuolleen vaikutelman. Oikeastaan pahinta ei ole varsinainen hävitys, palaneet talot ja metsät, kaatuneet puut, räjäytetyt sillat jne. vaan ennen kaikkea tämä elottomuus. Jäljellä olevissa taloissa (joissakin kylissä aika monta) ikkunat ja ovet ammottavat tyhjyyttään, pellot ovat viljelemättömiä, tiet ja polut umpeenkasvaneet, ja puutarhamaissa ei kasva muuta kuin rikkaruohoja ja siellä täällä kaiken keskellä jokin talvehtinut ja rehottava puutarhakasvi. (Eversti Sven Björkman vaimolleen 26.7.1941.) 
Kun on joutunut jättämään kotiseutunsa taakseen, kiinnittää vieraalla maaperällä ollessaan erityistä huomiota yhtäläisyyksiin ja yhteneväisiin piirteisiin maisemassa (Jürgenson 2015, 121-122). Tuttuus tuntemattomassa muistutti kodista ja vei ajatukset kotiseudulle. Rintaman vaarallisessa ja uhkaavassa maisemassa tarve löytää yhtymäkohtia todennäköisesti korostui. Artikkelin sotilaat olivat kotoisin rannikkoseudulta ja tottuneet elämään meren äärellä tai sen läheisyydessä. Parin kuukauden rintamalla olon jälkeen ylikersantti Curt Enrothin ja luutnantti Ulf Segerstrålen joukko-osastot sijoitettiin Viipurinlahdelle Suomenlahden rannikolle. Molemmat olivat kotoisin Uudeltamaalta ja kirjoittivat, kuinka hienoa jälleen oli "tuntea meri-ilma" (ylikersantti Curt Enroth vaimolleen 4.9.1941) usean viikon sisämaassa oleskelun jälkeen. Luutnantti Ulf Segerstråle kirjoitti merimaiseman merkityksestä kahdessa samana päivänä päivätyssä kirjeessä. Toisen hän lähetti äidilleen perheen kesänviettopaikkaan ja toisen siskolleen Porvooseen: "Eilen olimme Vilaniemellä ja näimme meren ensimmäistä kertaa kahden kesäkuukauden jälkeen. Tunsimme itsemme uusmaalaisiksi. Oli ihanaa nähdä avomeri autereessa ukonilman jälkeen." (Luutnantti Ulf Segerstråle äidilleen 25.8.1941.) "Meri kuohusi edessämme ja koin todellisen vapaan, ihanan tunteen siitä, että olen jälleen kotona kahden kuukauden soiden ja rämeiden keskellä kyyhöttämisen jälkeen." (Luutnantti Ulf Segerstråle siskolleen 25.8.1941.) Otteet osoittavat, kuinka tuttu näkymä ja äänimaisema loivat tunneperäisen siteen kotiin ja kuinka meri toimi tärkeänä yhtymäkohtana vieraan maiseman ja kotiseudun välillä. Meren äärellä luutnantti Ulf Segerstråle ja ylikersantti Curt Enroth saattoivat hetkeksi ajatuksissaan siirtyä kotiin (esim. luutnantti Ulf Segerstråle vanhemmilleen ja sisarelleen 19.7.1941).

Maanviljelijäperheen pojille Nils ja Göran Saxille maanviljelysmaisema toimi tärkeimpänä kosketuspintana kodin ja rintaman välillä. Sääolosuhteet rintamalla veivät ajatukset kotiin ja saivat heidät pohtimaan, miten työt mahtoivat sujua kotitilalla, mikäli sää oli siellä

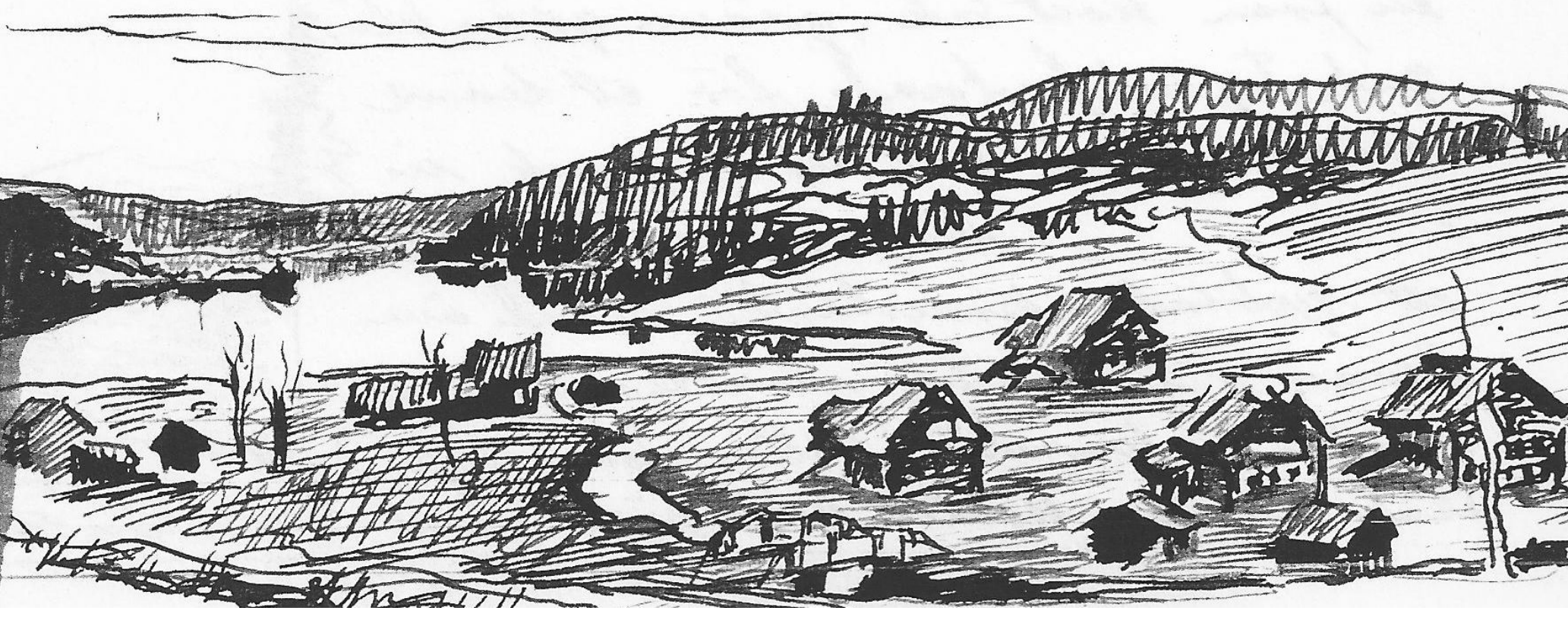

Kuva 1: Loppukesästä 1943 luutnantti ja taideopiskelija Ulf Segerstråle sai Kansallismuseolta tehtäväkseen maalata ja piirtää kirkkoja, ihmistyyppejä ja esineistöä eri paikkakunnilla Aunuksen kannaksella. Ulf Segerstråle piti näiden viikkojen ajan päiväkirjaa, jonka hän myös kuvitti luonnoksilla ja pienillä piirustuksilla. Näkymä Tuulosjärveltä 1.9.1943. (Kirjekokoelma: Ulf Segerstråle.) 
samanlaista: "Täällä sataa taas. En voi ymmärtää miten olette voineet saada heinät korjattua, jos siellä on satanut yhtä paljon kuin täällä", alikersantti Nils Sax ihmetteli kirjeessään vanhemmilleen 9. elokuuta 1942. (Ks. myös sotamies Göran Sax vanhemmilleen 1.5.1942.)

Suomen armeija ei pysähtynyt vanhalle rajalle vaan eteni kauas Itä-Karjalaan, alueille, jotka eivät koskaan olleet kuuluneet Suomelle. Kohdatessaan Itä-Karjalan maiseman sotilaat eivät niinkään havainnoineet yhtäläisyyksiä ja kaikkea tuttua vaan kiinnittivät erityistä huomiota eroavaisuuksiin. Monet asiat maisemassa herättivät ihmetystä ja ne koettiin vieraiksi. Oli selvää, että oli siirrytty kotimaasta muualle, vieraille seuduille - oli "kuin olisi Siperiaan karkotettu", kuten ylikersantti Curt Enroth kirjoitti vaimolleen 17. lokakuuta 1941. Eversti Sven Björkman kertoi vaimolleen ensivaikutelmastaan, kun hän ensimmäistä kertaa oli käynyt vanhan rajan takana - rajan, joka selkeästi sijaitsi läntisen sivistyksen ja itäisen barbarian välissä (Kosonen 2012, 193):

Rakkaani. Terveisiä ulkomailta. Olen tänään ollut n. 20 km päässä entisessä venäjän valtakunnassa. [...] Ryssien maa näyttää kyllä toivottomalta. Ei ole kahta kysymystäkään siitä, etteikö Aasia ala vanhan rajamme takaa. Lohduttomia, maalaamattomia, harmaita rakennuksia, surkeita kivisiä teitä, kaikki maanviljelyskalusto ja muut taloustavarat ikivanhoja [...]. Täällä on kyllä varsinainen Augeiaan talli puhdistettavana. (Eversti Sven Björkman vaimolleen 28.7.1941.)

Ei ole tavatonta, että sotilaat rinnastavat sotaretkensä ulkomaanmatkaan ja matkailuun. Se kuvastaa kokemusta siitä, että ollaan oman maan rajojen ulkopuolella ja nähdään alueita ja paikkoja, joissa normaaleissa oloissa ei olisi käyty. (Kivimäki 2014, 278; Ziemann 2007, 117; Fritz 1995, 234.) "Täällä on kyllä paljon kaikenlaista antiikkia ja uniikkia, mitä voisi tutkiskella, harmillista vain että täytyy matkailla [ruots. "turista"] tällaisissa olosuhteissa", ylikersantti Curt Enroth esimerkiksi kirjoitti vaimolleen 23. lokakuuta 1941 noin viikko vanhan rajan ylittämisen jälkeen.

Amerikkalainen kirjallisuustieteilijä ja toisen maailmansodan veteraani Samuel Hynes vertaa sotilaiden sotakuvauksia muun muassa matkakertomuksiin. Kaukana kotoa, sodan maisemassa sotilaat kohtaavat yleensä paljon sellaista, mikä tuntuu äärimmäisen vieraalta ja oudolta. Hynes käsittelee esimerkiksi Tyynenmeren sotaan osallistuneiden amerikkalaissotilaiden kertomuksia maisemista, joissa ei ollut mitään tunnistettavaa tai yhtymäkohtia kotiseudun maisemiin. (Hynes 1998, 5-7, 159-162.) Amerikkalaissotilaista poiketen suomalaissotilaat eivät liikkuneet kovin kaukana kotimaastaan, eivätkä olosuhteet ja ilmasto juuri poikenneet koti-Suomen oloista. Silti monet asiat herättivät inmetystä ja sotilaat kokivat olevansa vieraalla maalla. Maantieteellisen etäisyyden ei näin ollen välttämättä tarvitse olla pitkä, jotta maisema, ihmiset ja olosuhteet koettaisiin vieraiksi. (Kivimäki 2014, 270-280, 294-298.)

Vieraalla maalla liikkuessaan kirjeenkirjoittajat kiinnittivät erityistä huomiota siihen, miten kaikki tuntui olevan kovin vaatimatonta, alkeellista ja vanhakantaista verrattuna olosuhteisiin Suomessa. Suomen itsenäistymisen jälkeen oli etenkin oikeistolehdissä 1920- ja 1930-luvuilla tietoisesti rakennettu hyvin kielteinen kuva Neuvostoliitosta, bolševismista ja kaikesta, mikä liittyi venäläisyyteen. Osin tämä johtui vastenmielisyydestä Neuvostoliiton

2 Augeiaan tallit ovat Herakleen viides urotyö, kun Eurystheus antoi Herakleelle tehtäväksi yksin puhdistaa Augeiaan tallit yhdessä päivässä. Augeiaan talleja vertauskuvana käytettäessä tarkoitetaan asiaa, joka on jätetty hoitamatta ja on siten ajan kuluessa saanut ympärilleen törkyä. < https://fi.wikipedia.org/wiki/Augeias > [31.12.2017.] 
poliittista järjestelmää kohtaan, mutta etäisyydenotto voidaan myös nähdä tärkeänä osatekijänä suomalaisen kansallisen identiteetin rakentamisessa. (Luostarinen 1986, 191.) Myös jatkosodan alussa sanomalehdet ja aikakauslehdet sisälsivät runsaasti artikkeleita, joissa eri näkökulmista käsiteltiin takaisinvallattua Karjalaa ja erityisesti valloitettua Itä-Karjalaa. Teksteissä tuotiin muun muassa esille neuvostovallan perinpohjainen kyvyttömyys ja kelvottomuus. Monet kirjoittajat kirjoittivat kaikkialla vallitsevasta epäsiisteydestä ja alueen kurjuudesta ja jälkeenjääneisyydestä. (Luostarinen 1986, 236-244.) Kun aineistoni sotilaat liikkuivat Neuvostoliittoon kuuluneilla alueilla, näytti lehdistä välittynyt kuva saavan vahvistuksen. Takapajuisuus tuntui uskomattomalta: "Ei kyllä ole ollut aavistustakaan siitä, miten alkeellisesti jotkut tänä päivänä voivat elää. Näkisitpä heidän hevosensa, työkalunsa ja tavaransa!" ylikersantti Curt Enroth kirjoitti vaimolleen 21. lokakuuta 1941 muutama päivä sen jälkeen, kun patteristo oli ylittänyt vanhan rajan ja saapunut Paateneen seudulle Maaselän kannaksella.

Kielteiset lausumat maisemasta Neuvosto-Karjalassa liittyvät myös kysymykseen sodan päämääristä ja siitä, miksi taisteltiin. Artikkelin sotilaat suhtautuivat kielteisesti vanhan rajan ylitykseen ja tavoitteisiin luoda Suur-Suomi. (Esim. ylikersantti Curt Enroth vaimolleen 10.2.1943; luutnantti Ulf Segerstråle äidilleen 10.11.[1943]; sotamies Göran Sax vanhemmilleen 30.1.1944.) Tämä ei ole yllättävää, sillä harvat ruotsinkieliset suomalaiset asettuivat näiden suunnitelmien taakse. ${ }^{3}$ Kehityksestä jälkeenjääneiden alueiden valtaaminen ei kirjeenkirjoittajien mielestä ollut taistelemisen ja uhrausten arvoista: "Ei täältä löydy mitään sellaista, mitä viitsisi valloittaa. Ihan kuin olisi joutunut kivikaudelle. Kamalia teitä, savupirttejä ja kurjia peltotilkkuja, oikein varsinainen paratiisi", ylikersantti Curt Enroth kirjoitti vaimolleen 13. lokakuuta 1941. Paratiisi-sanan käytöstä kirjeissä löytyy muitakin esimerkkejä (esim. alikersantti Nils Sax vanhemmilleen 3.8.1941; 10.8.1941; sotamies Göran Sax vanhemmilleen 19.12. [po. tammikuu] 1942.) Aineistoni sotilaat olivat nähtävästi omaksuneet tiedotusvälineiden viljelemiä ironisia termejä, kuten "neuvostoparatiisi" ja "ihannemaa", joilla tehtiin pilaa naapurimaan harjoittamasta "menestyksen propagandasta". Neuvostoliiton välittämän kuvan katsottiin olevan äärimmäisessä ristiriidassa todellisuuden kanssa ja sen takia tällaiset ilmaisut olivat ajan myötä vakiintuneet tiedotusvälineissä Suomessa, mutta myös muualla. (Luostarinen 1986, 442-443; ks. myös Fritz 1995, 202-203.)

Rintamalla kohtaamansa uuden, vieraan ja toisenlaisen sotilaat peilasivat kotiympäristönsä elämäntapaan ja vertasivat sitä omiin kulttuurisiin käsityksiinsä ja käytänteisiinsä (Petrisalo 2004, 72). Vertaileminen toimii kulttuurisena tekniikkana, jonka avulla kirjoittaja paikantaa itsensä ja identiteettinsä. Ottamalla etäisyyttä vieraaseen maisemaan ja väheksymällä näkemäänsä vahvistettiin yhteyttä suomalaisuuteen ja omaan kotimaahan (Alsmark 1997, 11; Jürgenson 2015, 118-121). Alla olevassa otteessa kirjoittaja ilmaisee siteeraamalla säkeen Maamme-laulusta, kuinka Itä-Karjala ei tuntunut omalta maalta, kotimaalta, vaikka maiseman kauneus teki tietyn vaikutuksen:

3 Suur-Suomi-aatetta kannatettiin erityisesti Akateemisen Karjala-Seuran (AKS) ja samanhenkisten järjestöjen piirissä. Suur-Suomi-ideologia oli vahvasti kytketty aitosuomalaisuuteen ja heimoaatteeseen, joka sulki ruotsinkielisen väestönosan ulkopuolelle. On muun muassa tästä syystä ymmärrettävää, että ruotsinkieliset eivät varauksetta asettuneet Suur-Suomi-ideologian taakse. Suunnitelmia Suur-Suomesta ei kuitenkaan vastustettu ainoastaan ruotsinkielisten piirissä. Myös työväestön ja vasemmiston piireissä pyrkimyksiä oltiin laajalti vastaan. Luultavasti oli myös paljon niitä, jotka suhtautuivat kysymykseen enemmän tai vähemmän välinpitämättömästi. (Kivimäki 2014, 261-316; Kirves 2008, 31, 35-36.) 
Olin miellyttävällä sunnuntaikävelyllä korkealle vuorelle. Sieltä oli näkymä peninkulmien taakse ja jopa venäläiseen rautatieasemaan asti. Kyllä täällä korpea riittää. Lumeen peittynyttä pensaikkometsää riittää niin kauas kuin katse kantaa. Kaunista oli, mutta en minä kyllä kykene sanomaan: 'Ja tässä, täss' on tämä maa'. (Ylikersantti Curt Enroth vaimolleen 18.1.1942.)

Vaikka sotilaat kuvailivat kohtaamansa usein kielteisesti, löysivät he vieraasta maisemasta myös sellaista, minkä kokivat myönteiseksi. Edetessään itään sotilaat liikkuivat Itä-Karjalan koskemattomassa luonnossa ja maisemassa, jossa sodan väkivaltaisia merkkejä ei näkynyt. Tämän maiseman he usein kokivat uljaana, kiehtovana ja myös eksoottisena. Eversti Sven Björkman vieraili elokuun puolivälissä 1941 toisessa esikunnassa ja kuvaili kirjeessään vaimolleen automatkallaan näkemänsä maiseman:

Tie kulki läpi syvien aarniometsien, ja enimmäkseen neitseellisiä jokia pitkin, joiden yllä puut täysin vapaasti ja koskemattomana riippuivat. Ajoimme myös ohi kylän, joka sijaitsi suurella harjanteella (kylä on saanut nimensä siitä) ja sieltä oli rajaton, kiehtova näkymä korpien yli [...]. Ihmeellisen taianomainen maisema, joka ei voi olla tekemättä vaikutusta. (Eversti Sven Björkman vaimolleen 18.8.1941.)

Luutnantti Ulf Segerstrålelle luonto oli lapsesta asti ollut tärkeä ja myös rintamalla luonnonmaisemalla oli hänelle erityinen merkitys. Segerstråle kirjoitti usein runollisin tai romanttisin sanakääntein havainnoistaan; luonto oli "kaunis, rauhallinen, taianomainen" (esim. luutnantti Ulf Segerstråle vanhemmilleen ja sisarilleen 30.6.1941; sisarelleen 4.12.1941; äidilleen 16.12.1943; isälleen 12.1.1944). Hänen esteettisesti sävyttyneet kokemuksensa luonnosta voidaan kytkeä luontokäsitykseen, joka oli vallalla porvarillisessa kulttuurissa ja jossa luonto nähtiin kauniina, puhtaana, aitona sekä vastakohtana keinotekoiselle kaupunkimaisemalle. (Löfgren 1992, 53-54, 56-57.) Luonto toimi hänellä myös vastavoimana sodan tuhoamalle maisemalle ja kaikelle, mikä ihmisessä oli tuhoavaa. Luonnossa Ulf Segerstråle löysi "ikuisuuden, totuuden, rakkauden ja lainalaisuuden" (luutnantti Ulf Segerstråle isälleen 25.7.1941; äidilleen 12.1.1943). Rintaman luonnossa oli jälkiä sodan tuhovoimasta, mutta säästyneet alueet ja kaunis luonto muistuttivat, että jossakin oli vielä olemassa "normaali" maailma.

Matkalla korsuun [...] käpylintuparvi visersi lumen peittämässä koivussa. Ne herkuttelivat kävyillä ja lensivät viereiseen kuuseen hakemaan niitä lisää. Jäin katselemaan niitä pitkän tovin ja tein vaatimattomat johtopäätökseni. Hennot koivut lumen peittämineen oksistoineen, kuuraiset kannot ja erityisesti eilinen väliaikainen säänmuutos pilvisestä selkeään pilvimuodostelmineen ovat osoituksia siitä, että on olemassa maailma tämän mielipuolisuuden ohella, jossa nyt elämme. (Luutnantti Ulf Segerstråle äidilleen 19.1.1942.)

Kokemus luonnon ja tuhon kontrastista on saksalaisen historioitsijan Peter Knochin mukaan keskeinen piirre sotilaiden rintama-arjessa, ja näistä kokemuksista kirjoitettiin myös kirjeissä kotiin. Elävä luonto antoi voimia ja virkistystä ja muistutti kaikesta elävästä, minkä sota oli tuhonnut. (Knoch 1989, 230.) Taideopiskelijalle, joka mieluusti valitsi taiteensa aiheet luonnosta, luonnonmaisema rintamalla sai lisämerkityksen. Ulf Segerstråle löysi Syvärin luonnossa kodinomaisen paikan, joka herätti hänessä halun saada maalata: "Tietäisittepä kuinka toisinaan kaipaan tehdä jotakin luonnossa, luonnossa, josta on tullut kotini 'tällä puolella"' (luutnantti Ulf Segerstråle vanhemmilleen 12-15.2.1944; myös isälleen 17.5.1943). Asemasodan verrattain rauhallisina kuukausina Ulf Segerstråle sai useita mahdollisuuksia maalata ja piirtää. Monesti hän kuvitti kirjeitään pienillä piirroksilla ja maalasi akvarelleja Itä-Karjalan

4 Curt Enroth viittaa tässä Maamme-laulun kahdeksanteen säkeistöön: Ja tässä, täss' on tämä maa, // sen näkee silmämme. // me kättä voimme ojentaa // ja vettä rantaa osoittaa // ja sanoa: kas tuoss' on se, // maa armas isäimme. 
luonnossa. Luonto ja maalaaminen toimivat tärkeänä vastapainona kovalle ja henkisesti rasittavalle elämälle rintamalla.

\section{Rintamamaisema}

Maisemalla ja maastolla on aina ollut tärkeä rooli sotilaallisessa kontekstissa. Erilaiset sotilaalliset toiminnat, tehtävät ja operaatiot jättävät jälkensä ympäristöön sodan aikana, mutta myös rauhan oloissa. Tilan hallinta ja kontrollointi ovat tärkeitä aspekteja sotilaallisesta näkökulmasta, ja ympäröivä maasto on aina otettava huomioon strategisia ja taktisia päätöksiä tehtäessä. Myös yksittäisellä sotilaalla tulee olla kyky hahmottaa ja tulkita maisemaa. Sotilaan täytyy muun muassa tietää, miten maastoutua ja suojautua, miten liikkua äänettömästi partioretkillä ja osata erottaa eri aseiden ääniä ja reagoida niihin. Tällaiset kyvyt vaikuttavat ratkaisevasti sotilaan mahdollisuuksiin selviytyä hengissä sodasta. (Helphand 2006, 16; Woodward 2004, 3-4, 108-109.)

Teollisella sodankäynnillä on valtava tuhovoima, joka jättää äärimmäisiä jälkiä maisemaan. Samuel Hynes kutsuu täydellisen hävityksen ja tuhon kohteeksi joutunutta maisemaa sodan vastamaisemaksi. Sodan vastamaisemassa ei ole jäljellä enää mitään luonnollista tai "normaalia". Sodankäynti on myllertänyt maaperän, ja kasvillisuus ja puut ovat tuhoutuneet. Sen sijaan taisteluiden riisuma maisema on täyttynyt rojusta, kuolleista ruumiista, ruumiinosista, tuhoutuneista aseista ja rikki ammutuista ajoneuvoista. (Hynes 1998, 7-8.) Ensimmäisen maailmansodan taistelukenttiä länsirintamalla voidaan pitää sodan vastamaiseman perimmäisenä esimerkkinä. Talvisota toi sodan vastamaiseman myös Suomeen. Valtavalla tulivoimalla tykistö muokkasi maiseman tunnistamattomaksi ja vääristyneeksi Summan, Taipaleen ja Kollaan alueilla. (Laakkonen 2007a, 17; Laakkonen 2007b, 46.)

Sodankäynnin runtelemaa ja ruhjottua maisemaa saattoi olla vaikea pukea sanoiksi, ja tästä maisemasta artikkelin sotilaat pääosin vaikenivat kirjeissään. Muutamasta kirjeestä löytyy lyhyitä mainintoja ympäristöstä, jonka ehkä voi nähdä sodan vastamaisemana. Kesäkuun lopulla 1944 alikersantti Nils Sax kuvaili maisemaa rintamalohkollaan Karjalankannaksella, jossa juuri oli käyty kovia taisteluita Neuvostoliiton käynnistettyä suurhyökkäyksensä 9. kesäkuuta: "Täällä näyttää kyllä sotaisalta. Hevosenraatoja ja rikki ammuttuja vaunuja ja kanuunoita lojuu joka puolella ja siellä täällä on poroksi palaneita taisteluvaunuja." (Alikersantti Nils Sax vanhemmilleen 29.6.1944.) Sodan väkivaltaiset merkit maisemassa näkyivät vielä pitkään taisteluiden jälkeen. Kesällä 1942 eversti Sven Björkman kirjoitti vaimolleen näkymistä talvisodan taistelukentiltä, joilla valtava tulivoima oli muuttanut ympäristön hävityksen maisemaksi. Jäljet luonnonmaisemassa kertoivat hänelle myös niistä olosuhteista, joissa sotilaat olivat käyneet taistelua:

Kotona taas n. 20 tunnin automatkan jälkeen [...]. Sain nähdä monta paikkaa, joissa en ole ennen käynyt kuten Aittojoki, Tolvajärvi ja Kollaan-joki mainitakseni vain 3 kuuluisaa paikkaa talvisodasta. Viimeinen teki kyllä huiman vaikutuksen. Mitään niin sodan runtelemaa maisemaa en ole voinut kuvitellakaan. Täysin uskomatonta, että inmiset ovat voineet elää ja taistella siinä helvetintulessa, jonka on täytynyt raivota siellä yötä päivää. (Eversti Sven Björkman vaimolleen 30.6.1942.)

Eversti Sven Björkman kävi toukokuussa 1944 ohimennen Summan alueella ja kirjoitti, kuinka talvisodan kovat taistelut näkyivät edelleen maisemassa, vaikka maanpintaan oli jo alkanut nousta kasvillisuutta (eversti Sven Björkman vaimolleen 19.5.1944). Luonnon 
kulun lisäksi myös ihmisen toiminta normalisoi ajan mittaan vieraan ja tuhotun maiseman (Helphand 2006, 15). Eversti Sven Björkman kirjoitti tyytyväisenä ensimmäisen sotakesän lopulla, kuinka suomalaiset olivat välittömästi ryhtyneet rakentamaan ja korjaamaan tuhoja vallatuilla alueilla. Tällä toiminnalla ympäristö tehokkaasti muunnettiin omaksi, suomalaiseksi maisemaksi, jossa vallitsi Suomessa totuttu järjestys:

Muuten kyllä huomaa, että tämä maa on saanut uudet valtiaat. Kaikki sillat ovat korjattu, vahvistettu, ja ovat nyt hienoja, tiet alkavat näyttää autoteiltä meillä koti-Suomessa (pioneereilla on ollut tässä hirmuinen työ), puhelintolppia on noussut teiden varsille, pellot kynnetty jne. (Eversti Sven Björkman vaimolleen 29.8.1941.)

Vaikka kirjeet eivät juuri sisällä yksityiskohtaisia kuvauksia sodan vastamaisemasta, ne välittävät muilla tavoin, että maisema koettiin haasteellisena, uuvuttavana ja voimia vaativana. Maantieteilijä Rachel Woodward tähdentää, kuinka sotilaan arkielämä aina on vahvasti kytketty ympäröivään ympäristöön ja myös sääoloihin. Sotilaana olemiseen liittyy myös määrätyt tavat olla ja liikkua maastossa sekä käyttää ympäröivää maastoa hyväkseen. Hänen täytyy voittaa ne vaatimukset, jotka ympäristö, ilmasto ja taistelutoiminta asettavat ja löytää keinoja, joilla tehdä elämästä mahdollisimman siedettävää alkeellisissa ja riskialttiissa olosuhteissa. (Woodward 1998, 287-293.)

Rintamalla sotilaat joutuivat yleensä viettämään paljon aikaa ulkona eri tehtäviä hoitaessaan. He elivät mitä suurimmassa määrin luonnon ehdoilla ja sään armoilla, ja siitä syystä ympäröivä maasto ja varsinkin vaihtelut säässä vaikuttivat merkittävästi sotilaiden kokemuksiin elämästä rintamamaisemassa. Kesällä hyttyset kiusasivat, talvella kärsittiin kylmyydestä, ja

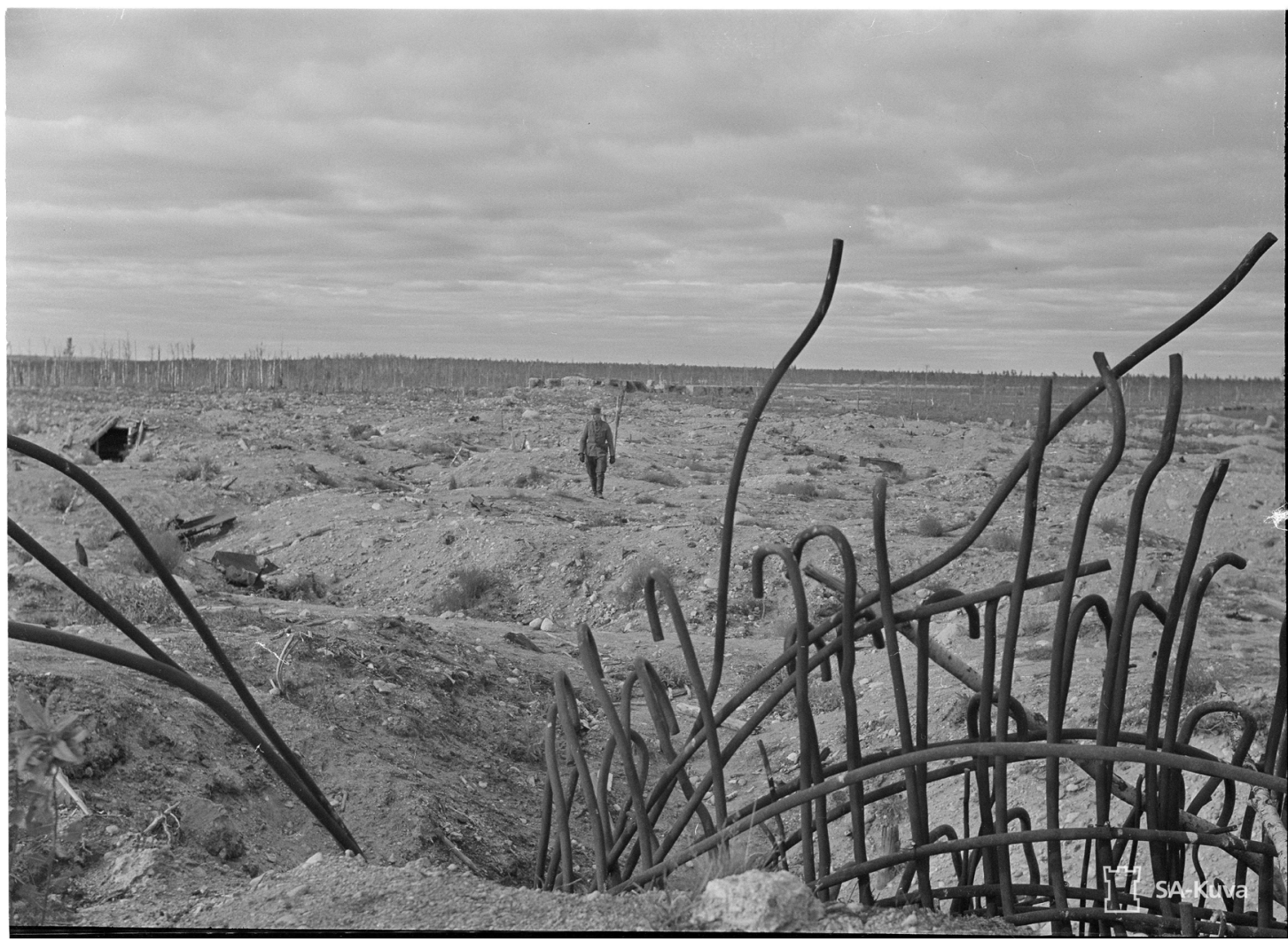

Kuva 2: Sodan vastamaisema Summassa. Summa, Lähteen lohkolta 26.9.1941. (SA-Kuva.) 
syksyisin ja keväisin routa ja runsaat sateet aiheuttivat tulvia vesiperäisillä alueilla täyttäen taisteluhaudat ja korsut vedellä. Keväällä 1942 alikersantti Nils Sax kirjoitti useaan otteeseen kurjista asuinolosuhteista heidän lohkollaan Karjalankannaksella. Korsut olivat veden täyttämiä ja miehet joutuivat tyhjentämään ne kolme neljä kertaa päivässä, jotta vesi ei nousisi makuulavitsaan asti. (Alikersantti Nils Sax vanhemmilleen 15.4.1942.) Vartiointi ja muut työt oli myös hoidettava kaikissa olosuhteissa. Seuraava ote lokakuussa 1942 kirjoitetusta kirjeestä osoittaa, kuinka ympäröivä sodan maisema ja kurjat sääolosuhteet vaikuttivat sotilaiden henkiseen kestokykyyn ja mielialaan musertavalla tavalla:

\begin{abstract}
Täällä sataa. Olemme kaikki läpimärkiä. Korsun katto vuotaa eikä meillä ole sadetakkeja kun menemme ulos vartioon. Kaikki vaatteet ovat ihan läpimärkiä. Ne jotka eivät ole täällä eivät kyllä ymmärrä kuinka hyvin heidän asiansa ovat. He eivät voi kuvitellakaan millaista tämä sotilaan elämä on. Juoksuhaudat ovat veden täyttämiä ja meidän täytyy maata vallilla mudassa ja kuulasateessa kun olemme vartiossa. [...] Vartiovuorot osuvat kohdalle niin usein, etteivät vaatteet ehdi kuivua niiden välillä. Yöllä vapaata on vain kaksi tuntia ja sitten täytyy taas mennä ulos mutaan ja sateeseen. Mikään ei enää huvita. Kuljemme täällä ympäriinsä kuin jotkin kummalliset eläimet. Mieli on ihan maassa. Kaikki ovat vilustuneet ja joka päivä joku lähtee sairaalaan ja taas on vähemmän miehiä ja enemmän vartiohommia muille. [...] Nyt minun täytyy lopettaa koska minun täytyy taas mennä ulos palelemaan kahdeksi tunniksi. [...] Lähettäkää paketti joskus niin että saa jotakin syötävää. Terveisin Nils. (Alikersantti Nils Sax vanhemmilleen 26.10.1942.)
\end{abstract}

Ote osoittaa, kuinka sietämättömät olosuhteet etulinjassa veivät elämänhalun ja riisuivat viimeisetkin rippeet ihmisarvoisesta elämästä. Tämän lisäksi ote kertoo kokemuksesta etäisyyden kasvamisesta kotirintaman ja rintaman välillä ja kuinka raskasta oli kohdata ymmärtämättömyyttä kotirintaman ihmisiltä. Alikersantti Nils Sax kuitenkin yritti välittää vanhemmilleen kokemuksiaan siitä, millaista oli elää uuvuttavissa olosuhteissa etulinjassa. Kurjat olosuhteet herättivät tarpeen saada jakaa ja purkaa synkkiä ajatuksia ja tunteita kirjeitse.

Sodan maisema oli monella tavalla epämiellyttävä ja kuvottavakin. Miehet kävivät lähes jatkuvaa taistelua lutikoita ja muita syöpäläisiä vastaan. (Esim. alikersantti Nils Sax vanhemmilleen 22.8.1942; ylikersantti Curt Enroth vaimolleen 10.12.1941, 29.1.1944.) Talousjätteet ja hautaamattomat ruumiit lisäsivät rottien määrää. Miehet kertoivat, kuinka rotat kasvoivat jopa kissan kokoisiksi ja kuinka vaikeaa niistä oli päästä eroon. Ylikersantti Curt Enroth valitti vaimolleen, miten hän oli eräänä yönä herännyt siihen, kun rotta juoksi hänen kasvojensa yli. Rotanmyrkky oli aluksi tehonnut, mutta pian rotat eivät enää siitäkään välittäneet. Miehet olivat kuitenkin onnistuneet pyydystämään muutaman ketunraudalla. Sotamies Göran Sax arveli, että he olivat ampuneet konepistoolilla ainakin 500 luotia korsussa asustavaa rottaa kohti tuloksetta. (Ylikersantti Curt Enroth vaimolleen 19.1.1943, 7.-8.3.1943, 5.5.1943; sotamies Göran Sax vanhemmilleen 2.12.1943.) Muun muassa rottien takia oli välttämätöntä haudata taistelukentille jääneet ruumiit heti, kun se oli mahdollista. Heinäkuussa 1942 alikersantti Nils Sax kertoi vanhemmilleen tästä tehtävästä ei-kenenkään-maalla: "Yöllä olimme piikkilangan edessä hautaamassa kaatuneita venäläisiä. Toiset olivat maanneet siellä talvesta saakka ja heillä oli turkikset ja lumipuvut päällään. Voitte kuvitella kuinka siellä haisi." (Alikersantti Nils Sax vanhemmilleen 14.7.1942.)

Ei-kenenkään-maa Suomen ja Neuvostoliiton etulinjojen välissä voidaan nähdä välitilana, jota taistelevat osapuolet pyrkivät hallitsemaan, mutta jota kumpikaan ei hallinnut. Ei-kenenkään-maa toimi rajana tunnetun ja tuntemattoman välillä. Piikkilangan omalla puolella olosuhteet olivat tiedossa, mutta sen toisella puolella sijaitsi tuntematon, vaarallinen, 
pelottava maailma. (Leed 2009, 14-15.) Vaikka ei-kenenkään-maa oli välitila, se ei ollut tyhjä tila. Miinojen, piikkilankojen, espanjalaisten ratsujen ${ }^{5}$ ja muiden siirrettävien puolustusesteiden tarkoituksena oli vaikeuttaa vihollisen liikkumista tilassa. Sotilaat liikkuivat ei-kenenkään-maalla muun muassa partioretkillään ja linnoitustöissä. Sotamies Göran Sax joutui useita viikkoja loppusyksystä 1943 öisin tekemään töitä ei-kenenkään-maalla. Aluksi hän oli vetämässä piikkilankaa linjan eteen ja sen jälkeen tehtävänä oli kaivaa tunneli ja rakentaa korsu pieneen tukikohtaan keskelle ei-kenenkään-maata. Tehtävä oli erittäin vaarallinen ja herätti hänessä kuolemanpelkoa, mutta myös vihaa niitä esimiehiä kohtaan, jotka olivat määränneet hänet tehtävään. Hän koki, että sai tehtävän rangaistuksena siitä, että hänelle aiemmin syksyllä oli myönnetty muutaman viikon maatalousloma. (Sotamies Göran Sax vanhemmilleen 5.10.1943.) Jokaisessa kirjeessä tältä ajalta hän kertoi työstään ei-kenenkään-maalla, "jossa kukaan ei halua olla" (sotamies Göran Sax vanhemmilleen 6.10.1943):

Kyllä nämä päivät ovat minulle niin raskaita vaikka päivisin ei tee mitään. Mutta kun ajattelee että joka ilta ja yö täytyy lähteä sinne ei-kenenkään-maalle tekemään töitä pimeässä ja kurjuudessa, mikään ei enää haluta, ei tahdo saada unta eikä ruoka maistu. Tämä on kyllä pahinta mitä elämässäni olen kokenut eikä siitä pääse pakoon ja joka ilta kaikki vaan pahenee. Eilen illalla ne taas tulittivat meitä, ja kaksi haavoittui, yksi sai sirpaleen jalkaansa ja toinen kuulan reitensä läpi. Niin että ei sitä tiedä minä hetkenä tahansa voi itsekin menettää henkensä. (Sotamies Göran Sax isälleen 8.10.1943.)

Vihollinen on olennainen osa rintaman maisemaa, vaikka sotilaat harvoin näkivät tai kohtasivat tämän (Kivimäki 2014, 296). Vihollisen toiminta vaikutti monin tavoin rintamamiesten arkeen ja rajoitti heidän liikkumistaan myös omissa asemissa. Tammikuun lopulla 1943 alikersantti Nils Sax valitti kirjeessään veljelleen, ettei "huussiinkaan" tahtonut päästä kulkemaan vihollisen tulituksen takia (Nils Sax Göranille 28.1.1943).

Sota ja sotatoimet tuottavat myös omanlaisensa äänimaiseman, johon kuuluu muun muassa räjähdyksiä, papatusta, huutoa ja jyskettä. Melu täytti rintamamaiseman ja erotti tämän rauhanaikaisesta, arkisesta ja normaalista maisemasta. Äänimaiseman käsitteeseen kuuluu myös yksilöllisiä tapoja ymmärtää ja kokea ääniympäristö. Ajoittainen lähes taukoamaton meteli, jylinä, jyske, rätinä ja ryske, jonka pikakiväärit, konekiväärit, kranaatinheittimet, haupitsit ja tykit aiheuttivat, oli monille sotilaille äärettömän raskasta ja kulutti heidän henkisiä voimavarojaan. (Ampuja 2007, 305-306, 323.) Kokemuksia rintaman pelottavasta ja rasittavasta äänimaisemasta saattoi olla vaikeaa sanallistaa. Sotamies Göran Sax yritti kuitenkin kirjeessään kotiin löytää sopivia sanoja ilmaisemaan kokemuksiaan ja tunteitaan, jotka vihollisen tulitus ja tykistön aiheuttamat äänet herättivät hänessä kesäkuussa 1944 vihollisen hyökätessä: "Olen kaivautunut kallioseinämän viereen mutta ei sitä saa unta kun joutuu olemaan taivasalla ja kaiken lisäksi pauhaa niin kuin pahimmassa noidankattilassa" (sotamies Göran Sax vanhemmilleen juhannusaattona 23.6.1944). Pari päivää myöhemmin hän palasi asiaan:

Alan olla niin hermostunut etten tiedä miten tästä selviää. [...] Kyllä on hirveätä kun niillä on niin paljon tykistöä ja ampuvat. [...] Hermoni alkavat olla ihan riekaleina tämän sodan seurauksena eikä tiedä mitä tekisi kun kuulee kranaatin äänen, olen saanut niin kamalan kammon. (Sotamies Göran Sax vanhemmilleen 25.-26.6.1944.)

\footnotetext{
5 "Espanjalainen ratsu" on siirrettävä piikkilankaeste, joka koostuu puukehikosta ja siihen kiinnitetyistä piikkilangoista. (Nationalencyklopedin, < http://www.ne.se.ezproxy.vasa.abo.fi/uppslagsverk/encyklopedi/lång/spansk-ryttare > [8.1.2018.]
} 
Osa äänistä rintamalla tarkoitti vaaraa ja osa ei. Sotilaille oli tämän takia tärkeätä osata arvioida äänet oikein ja reagoida niihin nopeasti tarvittaessa. Sodan äänimaisemaan kuuluu kuitenkin myös "normaaleja", luonnon ääniä, kuten linnunlaulua (Ampuja 2007, 304-310, 333-336):

Klo 12 lähdimme kaikki matkaan ja miehitimme kannaksen, jossa venäläisten on tapana käydä. Kolmen tunnin ajan koimme kuinka tähdet sammuivat, alkoi sarastaa ja usva tiheni samalla kun pari minulle tuntematonta kerttua lauloivat ihanasti lehdossa edessämme. Klo 3.00 rähinä sitten alkoi. [...] Kaikki aseet tulittivat ja venäläisiltä jäi jälkeen yksi kuollut, jonka raahasimme mukanamme. (Luutnantti Ulf Segerstråle äidilleen 28.7.1941; ks. myös Ulf Segerstråle vanhemmilleen ja sisarilleen 30.6.1941 sekä isälleen 5.9.1941; 25.5.1942.)

Luutnantti Ulf Segerstrålella oli partioretkistään ja taistelutehtävistään kertoessaan tapana yhdistää kuvauksissaan sodan aineksia luonnon elementteihin. Runollisin sanakääntein hän kuvaili havaitsemaansa ja kuulemaansa. Luonnon tulkitseminen on tärkeä osa sotilaan kompetenssia, mutta Ulf Segerstrålen tapauksessa yhdistäminen täytyy nähdä lähinnä keinona välittömästi silottaa ja tyynnyttää sodan maiseman kauhuja jollakin, mikä tuntui turvalliselta, normaalilta ja luonnolliselta. Hänen kirjeensä osoittavat hänen olleen vastuun- ja velvollisuudentuntoinen upseeri (Hagelstam 2014, 164-181), mutta kertomalla kauniista maisemista ja laulavista linnuista keskellä taistelutannerta hän ilmaisi olevansa edelleen se luontoa rakastava poika, jonka hänen perheensä aina oli tuntenut. Luonto ja taide pitivät hänet sodasta huolimatta yhteydessä siviilielämäänsä.

\section{Maiseman haltuunotto}

Rintaman vieraissa, vaarallisissa ja turvattomissa oloissa syntyi tarve luoda ympäristö, joka tarjosi sotilaille suojaa ja turvallisuuden tunnetta. Hyökkäysvaiheessa 1941, kun rintama jatkuvasti siirtyi edemmäksi, ei ollut aikaa eikä tarvetta rakentaa kunnollisia asumuksia tai kenttävarustuksia. Uuteen paikkaan tultaessa jouduttiin tämän takia ensimmäisenä tehtävänä kaivamaan tilapäiset asemat ja useimmiten asuttiin teltoissa. (Helamaa 1983, 17-19.) Kun sota pitkittyi ja seisahtui asemasodaksi, vierasta ja vallattua maisemaa alettiin ottaa haltuun pysyvämmillä rakennelmilla, muun muassa linnoittamalla, varustelemalla ja rakentamalla.

Armeijan muokkaamalle maisemalle on ominaista, että se on naamioitu, maahan kaivettu, rajoitettu, valvottu ja kontrolloitu tila. Maisema muotoutui sotilaiden toimesta vuorovaikutuksessa armeijan tarpeiden ja olemassa olevan maaston ja luonnon välillä. Majoitusaluetta valittaessa oli ensisijaisesti otettava huomioon sotilaalliset tarpeet. Paikan tuli tarjota tarpeeksi suojaa ja naamioimismahdollisuuksia, mutta oli myös tärkeää, että maaperä oli mahdollisimman kuiva ja että rakennusaineita sekä juoma- ja pesuvettä oli saatavilla läheltä. Armeijan taholta annettiin ohjeita siitä, miten maastoon piilotetut rakennukset tuli sijoittaa, mitä rakennusaineita tuli käyttää ja miten rakennukset piti naamioida. Etelä- ja länsirinteitä pidettiin edullisimpina rakennuspaikkoina, koska niille osui eniten auringonvaloa. Myös esimerkiksi tuulisuhteet oli syytä ottaa rakennusten sijoittamisessa huomioon. (Rakennusopas kenttämajoitusta varten 1943, 7-13.) Seuraavassa eversti Sven Björkman kertoo, kuinka maisema oli muokattu niin, että se antoi suojaa ja mahdollisuuksia liikkua etulinjassa ilman, että sotilaat joutuivat alttiiksi liian suurille vaaroille: 
näkymättömissä ja enimmäkseen vihollista etelässä katsellaan epäsuorasti periskoopilla tai vastaavalla. Näin niissä kohdissa, joissa linjat ovat lähellä toisiaan, mutta enimmäkseen välimatka on melko iso, ja siellä voi hyvin ottaa enemmän vapauksia. Tänään olin mm. tukikohdassa, joka sijaitsee syrjässä keskellä suota. Se oli kuin pieni linnake ympäröivine valleineen ja asuntokorsut sen keskellä. (Eversti Sven Björkman vaimolleen 7.9.1943.)

Maastoa ei rakennettu ja muokattu ainoastaan sotilaallisten tarpeiden mukaan. Kun tilanne rintamalla vakiintui, tehtiin myös rakennuksia, jotka eivät olleet välttämättömiä, mutta jotka lisäsivät viihtyisyyttä ja mukavuutta. Suuria ja näyttäviäkin asevelitaloja, kanttiinirakennuksia ja sotilaskoteja pystytettiin rykmenttien ja pataljoonien yhteyteen. (Esim. sotamies Göran Sax vanhemmilleen 19.4.1943.) Komentopaikat ja komentokorsut olivat usein myös edustavia ja jopa pröystäileviä. Monissa joukko-osastoissa palveli miehiä, jotka siviiliammatiltaan olivat arkkitehtejä, ja he saivat tehtäväkseen laatia piirustuksia eri rakennuksia varten, mikä osaltaan selittää, miksi rintamalle nousi muun muassa funktionalismista vaikutteita saanutta "korsuarkkitehtuuria". Koristeaiheissa otettiin melko usein vaikutteita karjalaistaloista, mutta inspiraatiota saatiin myös suomalaisarkkitehtuurista, kuten Alvar Aallon suunnittelemasta Villa Maireasta, ja näin pala Suomea siirrettiin keskelle Itä-Karjalan maisemaa. (Helamaa 1983, 28-44, 47-59.)

Hiljaisessa asemasotavaiheessa rakennettiin myös erilaisia urheilukenttiä joukko-osastojen yhteyteen. Sotilaille ryhdyttiin nimittäin tarjoamaan erilaisia ajanvietemahdollisuuksia, joiden tarkoituksena oli torjua sotaväsymystä ja pitkästymistä (esim. Lappalainen 1991, 36). Luutnantti Ulf Segerstråle toimi urheilu-upseerina asemasodan aikana ja hänen kirjeensä sisältävätkin useita mainintoja urheilutoiminnasta ja niistä puitteista, joita toiminnalle luotiin. Kesällä 1942 hän kertoi, kuinka he talkoovoimin raivasivat ympäristöä ja saivat aikaan jalkapallokentän, kuulantyöntö- ja korkeushyppypaikan sekä 400 metrin juoksuradan. Syksyllä 1942 rykmentissä rakennettiin iso urheiluhalli, jossa oli tilat muun muassa lentopallolle, tenniksen peluulle, voimistelulle, nyrkkeilylle ja painille. (Esim. luutnantti Ulf Segerstråle isälleen 30.7.1942; sisarelleen 1.12.1942; 4.12.1942.)

Ympäristön haltuunotto ei kuitenkaan tapahtunut vain armeijan toimesta. Yksittäiset sotilaat ja heidän toverinsa ottivat myös omasta aloitteestaan maisemaa eri keinoin haltuun. Saksalaisen etnologin Ina-Maria Greveruksen mukaan ihmisellä on perustava tarve kiinnittyä tiettyyn paikkaan. Hän puhuu territoriaalisesta inmisestä, joka pyrkii pitämään hallussaan määrättyä paikkaa, jota voi kutsua omakseen ja johon voi samaistua. Tämä paikka voi olla esimerkiksi talo, seutu tai maa. Tarve liittyy mahdollisuuteen luoda turvallisuuden tunnetta aineellisella ja sosiaalisella tasolla sekä mahdollisuuteen identifioitua sosiaaliseen ryhmään. Koti tai kotiseutu on paikka, johon ihminen on tunnetasolla sitoutunut ja jonka varaan ihminen rakentaa paikallisuutensa. (Greverus 1972, 51-54.) Rintamalla omasta korsusta tuli ensisijainen paikka, jossa sotilaat tunsivat olevansa "kotonaan". Oma korsu toimi kiinnekohtana, johon miehet pystyivät paikantamaan oman sijaintinsa suhteessa ympäröivään rintamamaisemaan. Korsu kiinnekohtana loi turvallisuuden tunnetta, järjestystä ja elämänhallintaa epävarmoissa olosuhteissa rintamalla. (Vrt. Sallinen 2004, 86.)

Etulinjan korsujen ensisijainen tehtävä oli tarjota sotilaille välttävä majapaikka, joka suojaisi tykistötulelta ja joka kestäisi kaikissa sääoloissa. Asemasodan rauhallisissa oloissa tuli kuitenkin mahdolliseksi lisätä asunnon mukavuuksia ja korsuja rakennettaessa alettiin kiinnittää yhä enemmän huomiota lämpöön, valaistukseen ja kuivuuteen. Korsujen viihtyisyyden luominen oli kuitenkin asujien oman viitseliäisyyden varassa. (Lappalainen 1990, 23.) 
Aineistossani erityisesti tykistössä palvellut ylikersantti Curt Enroth kirjoitti melko yksityiskohtaisesti korsujen rakentamisesta ja sisustamisesta. Tykistö sijoitettiin aina takamaastoon, missä etulinjaan verrattuna asumisen laatuun voitiin kiinnittää suurempaa huomiota. Curt Enrothille rakentaminen tuntui olevan mieluisaa ja hän kertoi tyytyväisenä vaimolleen, kuinka he tekivät muutoksia asunnon pohjakaavaan, jotta asumisesta tulisi toimivampaa (ylikersantti Curt Enroth vaimolleen 9.6.1942; 9-10.11.1942; 29.6.1943). He lisäsivät viihtyisyyttä myös valmistamillaan huonekaluilla ja Curt Enroth kertoi ylpeänä nikkaroineensa hyllyjä ja kaappeja korsuun.

No, nyt meillä ainakin on kunnon katto pään päällä [...]. Näkisitpä kuinka hieno pieni alkovimme on. [...] Ja näkisitpä hyllyni, piippuhyllyni sängyn pääpuolen vieressä ja askelsäästökaappini keittiötarvikkeineen. [...] Tänään olen nikkaroinut hyllyt kaikkien sänkyjen viereen ja kaksi muuta tekivät pöytiä ja penkkejä. (Ylikersantti Curt Enroth vaimolleen 8.7.1943.)

Ylikersantti Curt Enroth tiesi vaimonsa mielellään kuulevan, miten hän ja muut miehet asuivat ja elivät. Vaimo koki nimittäin olevansa lähempänä miestään, kun hänellä oli jonkinlainen käsitys siitä, millaisessa ympäristössä hänen miehensä eli (esim. Martha Enroth miehelleen 9.3.1942; 14.11.1942). Korsujen ulkopuolelle rakennettiin puutarhakalusteita, jotta lämpimään vuodenaikaan päästiin sisätilan ahtaudesta ja voitiin viettää enemmän aikaa ulkona (ylikersantti Curt Enroth vaimolleen 1.5.1942; 18.6.1943). Sodan rauhallisina kuukausina sotilaat ryhtyivät myös kaunistamaan maisemaa istutuksin (ylikersantti Curt Enroth vaimolleen 27.5.1943; 25.6.1943; 22.5.1944; alikersantti Nils Sax veljelleen Göranille 23.5.1943). Tähän tarvittiin kuitenkin apua kotirintamalta:

\footnotetext{
Korsun ulkopuolelle olemme ajatelleet perustaa kukkamaita ja huomenna ajamme sinne lannoitetta ja maata. Eteläpuolelle suunnittelemme keittiöpuutarhaa ja pyytäisin sinua puhumaan rouva Malmströmin kanssa. Juttelin hänen kanssaan kun viimeksi olin lomalla ja hän kertoi, että saavat siemeniä maaliskuussa. a) Kurkkuja, porkkanoita, punajuuria, retiisejä b) Kehäkukkia, krasseja, daalioita, auringonkukkia. Kauneudennälkä on vallannut mielemme ja aiomme raivata joelta pienen metsittyneen niemekkeen. (Luutnantti Ulf Segerstråle äidilleen 26.3.1943.)
}

Kasvimaiden sato antoi tarpeellisen lisän sotilaiden ruokavalioon, mutta puutarhojen perustaminen voidaan nähdä myös keinona "kesyttää" ympäröivä maisema ja tehdä siitä oma. Puutarhat ovat ihmisen ja paikan vuorovaikutuksen tuotteita ja kertovat sopeutumisesta vaativiin olosuhteisiin. Amerikkalainen maisema-arkkitehti Kenneth Helphand on tutkinut puutarhojen perustamista erilaisiin äärioloihin, kuten ensimmäisen maailmansodan juoksuhautojen yhteyteen, toisen maailmansodan sotavankileireille, juutalaisgetoissa Euroopassa ja japanilaisten internointileireissä Yhdysvalloissa. Helphand osoittaa, kuinka kasvi- ja kukkamaiden perustaminen toimi selviytymiskeinona, sillä puutarhat kasvavine taimineen symbolisoivat toivoa, lohtua, tulevaisuudenuskoa ja elämää kaaoksen ja kuoleman keskellä. Kasvi- ja kukkamaat toimivat myös kontrastina sodan tuhoamalle maisemalle, loivat viihtyisyyttä ja toivat kauneutta paikkoihin, missä sitä ei välttämättä ollut. Tämän lisäksi puutarhat tarjosivat mielekästä ja hyödyllistä tekemistä, mikä myös oli tärkeää selviytymisen kannalta. (Helphand 2006, 1-20, 211-242.) Rintaman äärimmäisissä olosuhteissa puutarhojen perustaminen oli luovuutta vaativa tapa ottaa maisema haltuun.

Ina-Maria Greverukseen viitaten virolainen etnologi Aivar Jürgenson painottaa, että vieraan maiseman haltuunotto ja muokkaaminen läheiseksi on useasti luova prosessi (Jürgenson 2015 , 122). Kuten yllä mainittiin, vieraassa ympäristössä kiinnitetään ensisijaisesti huomiota 
sellaiseen, mikä vaikuttaa tutulta. Kun mitään tuttua ei ole, sinne luodaan sellaista, mikä tuntuu tutulta. Kotiseudusta ja kaikesta, mikä tuntui omalta, läheiseltä ja tutulta ei näin ollen luovuttu rintaman vieraassa ympäristössä. Päinvastoin, monta arkista, normaalia, rauhanaikaista toimintaa siirrettiin rintaman arkeen (vrt. Jürgenson 2015,118 ). Sotilaat kantoivat mukanaan kotiyhteisössään omaksumaansa kulttuuria ja perinteitä, sen arvoja, normeja, tapoja ja tottumuksia (Petrisalo 2004, 72). Rintamalla näistä pidettiin kiinni: siisteyttä ja järjestystä pyrittiin ylläpitämään (luutnantti Ulf Segerstråle äidilleen 3.6.1942; ylikersantti Curt Enroth vaimolleen 9.6.1942) ja joulua ja muita vuotuisjuhlia vietettiin mahdollisuuksien mukaan perinteitä kunnioittaen. Kotiväki osallistui monin tavoin rintamamiesten pyrkimyksiin luoda jatkuvuuden tunnetta. Paitsi siemeniä,

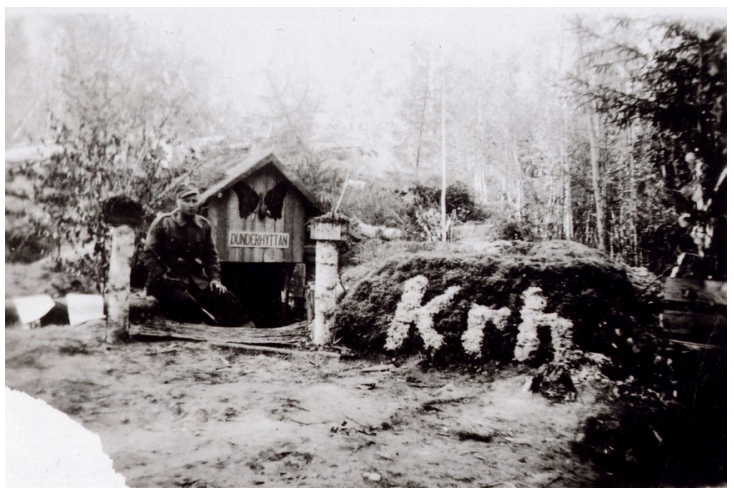

Kuva 3: Sotamies Göran Sax korsunsa edessä. Maastoon piilotetun asuntokorsun tuli tarjota sotilaille suojaa tulelta ja siksi ne naamioitiin, vahvistettiin ja kaivettiin syvälle maahan. Asemasodan aikana maisemaa myös kaunistettiin. Kuva otettu kesällä 1942 jalkaväkirykmentti 61:n alueelta Syvärillä. (Kuva: Saxin suvun hallussa.) kotoa lähetettiin myös astioita, sisustustekstiilejä, joulukoristeita ja paljon muuta, joilla arkielämää rintamalla normalisoitiin. (Aiheesta enemmän Hagelstam 2014.) Paikka otettiin näin ollen haltuun monien arkisten käytänteiden avulla.

Vierasta maisemaa otettiin haltuun myös diskursiivisella, kerronnallisella tasolla. Marraskuun 29. päivänä 1941 päivätyssä kirjeessä luutnantti Ulf Segerstråle kirjoitti, että hän oli "juuri tullut kotiin" partioretkeltä. Samoihin aikoihin ja varsinkin vuoden 1942 alkupuolelta lähtien sana "koti" ilmestyy yhä useammin myös eversti Sven Björkmanin ja ylikersantti Curt Enrothin kirjeisiin. (Esim. eversti Sven Björkman vaimolleen 21.10.1941; 23.1.1942; ylikersantti Curt Enroth vaimolleen 23.5.1942; 3.7.1942.) Vuoden 1942 alkupuolella sodankäynti jähmettyi asemasodaksi ja joukko-osastot jäivät pidemmiksi ajoiksi paikoilleen. Pysyvämmissä asemissa ehdittiin asettua aloilleen ja koti-sanan käyttöä voidaan pitää merkkinä siitä, että sotilaat olivat ainakin jossakin määrin sopeutuneet ja mukautuneet paikkaan ja tunsivat siihen jonkinasteista kuuluvaisuuden tunnetta. Koti-sanan käyttö voidaan näin ollen nähdä kielellisenä tekniikkana, jonka avulla vieras maisema otettiin haltuun.

Ina-Maria Greverus painottaa, että kodin maantieteellisellä sijainnilla ei oikeastaan ole merkitystä vaan ihminen voi tuntea olevansa kotona missä tahansa (Sallinen 2004, 86). Vaikka sotilaat kykenivät luomaan tiettyä kuuluvuuden tunnetta rintamalla ja käyttivät koti-sanaa asumuksestaan, on tärkeää huomioida, että korsu ei koskaan ollut koti suhteessa siviiliin kotiin. Joissakin tapauksissa kirjoittaja varusti sanan lainausmerkeillä, mikä osoittaa tietoisen ja joissakin tapauksissa myös ironisen käytön, mutta kirjeistä löytyy myös esimerkkejä siitä, että kirjoittaja luultavasti valitsi sanan automaattisesti ja lähes tiedostamattaan. (Esim. ylikersantti Curt Enroth vaimolleen 28.4.1942.) "Rintamakodista" huolimatta lojaliteetti siviilikotiin säilyi vahvana läpi koko sodan. Rintaman koti oli koti ainoastaan suhteessa muihin paikkoihin rintamalla. Oma korsu toimi rintamalla kodinomaisena lähtö- ja paluupaikkana ja kodin korvikkeena (vrt. Colville 2009, 499-500), kun turvattomuus synnytti tarpeen luoda suojaisan tilan, jonka ulkopuolelle jäivät rintaman uhat ja vaarat. 
Paikan haltuunotto jouduttiin sotavuosina toistamaan monta kertaa. Joukko-osastot siirtyivät useamman kerran sodan aikana uusille lohkoille, joissa rakennustoiminta ja maiseman haltuunotto täytyi suorittaa uudelleen. Muutot koettiin rasittavina ja epämiellyttävinä ja siirtymiset paikasta toiseen herättivät sotilaissa ärtymyksen ja rauhattomuuden tunteita. Tuntui turhauttavalta joutua jättämään suurella vaivalla rakennetut korsut ja asemat ja aloittaa rakennustyöt uudella paikalla (esim. alikersantti Nils Sax vanhemmilleen 11.6.1942). Sotilaat olivat myös sodan kuluessa oppineet, että kestäisi jonkin aikaa ennen kuin uudessa paikassa jälleen tuntisi olonsa kotoisaksi (esim. sotamies Göran Sax vanhemmilleen 21.11.1942). Ylikersantti Curt Enroth kirjoitti vaimolleen vierauden tunteesta uusissa asemissa ja siitä miten omituiselta tuntui, että myös rintamalla kiintyi paikkaan: "Nyt alkaa myös tuntua siltä että on kotiutunut tähän paikkaan. Ensimmäinen vuorokausi muuton jälkeen on aina kaikkein pahin, kun olosuhteet tuntuvat niin vierailta." (Ylikersantti Curt Enroth vaimolleen 16.8.1941.)

[...] toisekseen minulla on se tympäisevä tunne, mikä aina seuraa muuttoja. Sen kai olet huomannut? Ei ole ollenkaan hauskaa että meidät paiskataan sinne ja tänne, mieluiten olisi samassa paikassa. Sillä niin ihmeelliseltä kuin se tuntuukin, niin myös täällä syntyy jonkinlainen kodin tuntu. (Ylikersantti Curt Enroth vaimolleen 13.7.1942.)

Muutot aiheuttivat aina katkoksen sotilaiden rintama-arjessa ja toivat mukanaan epävarmuutta ja epätietoisuutta siitä, mitä tulevaisuus toisi tullessaan. Olisiko uusi paikka vaarallisempi? Olisivatko asumisolosuhteet huonommat uudella lohkolla? Oltuaan pidempään samalla paikalla ja perehdyttyään maisemaan ja maastoon sotilaat olivat muodostaneet käsityksen lohkon riskeistä ja vaaroista. Lähiympäristön tuntemus loi turvallisuuden tunnetta sekä kontrollin ja hallitsemisen kokemuksen, mikä oli tärkeätä sotilaille, jotka joutuivat pitkään elämään rintaman äärimmäisen epävarmoissa oloissa.
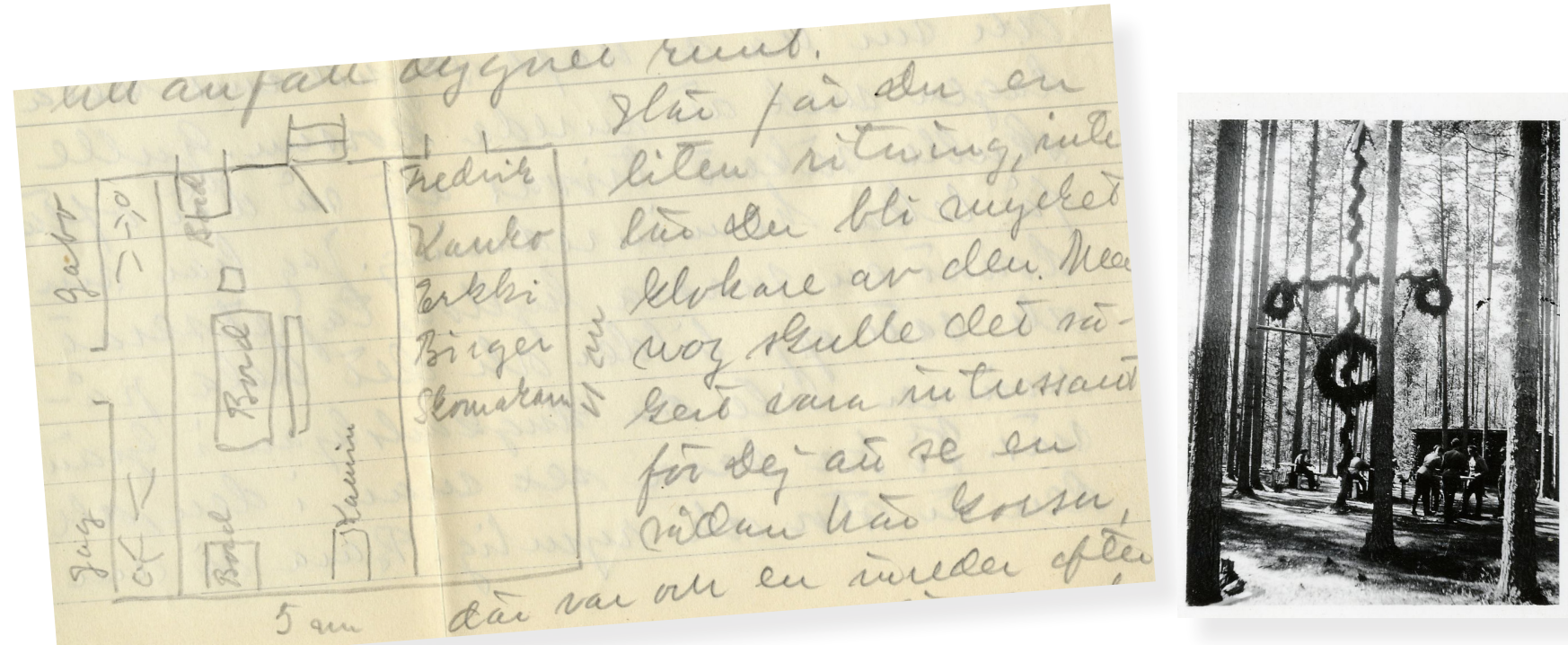

Kuva 4: Sotilaat kuvittivat kirjeensä joskus korsun pohjapiirustuksella uuden asunnon valmistuttua, jotta kotiväki saisi käsityksen asumisolosuhteista. Piirustukseen merkittiin aina oma makuupaikka. Piirustus löytyy ylikersantti Curt Enrothin 9.6.1942 päivätystä kirjeestä. (Kirjekokoelma: Enroth, Curt ja Martha.)
Kuva 5: Rintamalla vietettiin mahdollisuuksien mukaan vuotuisjuhlia. Jalkaväkirykmentti 24:ssä pystytettiin kesällä 1942 juhannussalko kanttiinin yhteyteen. Luutnantti Ulf Segerstråle lähetti valokuvan äidilleen 14. syyskuuta päivätyssä kirjeessä. (Kirjekokolema: Ulf Segerstråle.) 


\section{Sodan maisema sotilaiden kirjeissä}

Tämän artikkelin keskeisenä tavoitteena on ollut analysoida, miten rintamamiehet kokivat maiseman, mitä ajatuksia ja tunteita se heissä herätti ja kuinka he arjen käytännöissään ottivat vieraan maiseman haltuunsa ja muunsivat sen omaksi. Sotilaille sodan ja rintaman maisema oli monin tavoin ristiriitainen. Jatkosodan aikana suomalaiset sotilaat kohtasivat sodan tuhoaman, runteleman ja vääristämän maiseman, toisaalta "bolševikkiparatiisin" primitiivisyyden ja toisaalta taas Itä-Karjalan koskemattoman ja kauniin luonnonmaiseman.

Kirjeissään kotiin sotilaat kuvailivat havaitsemaansa ja näkemäänsä. Pukemalla näkemäänsä sanoiksi kirjeissä he rakensivat kuvia rintamamaisemasta - kuvia, jotka sotilaat eri syistä halusivat tai kykenivät jakamaan läheistensä kanssa. Kirjeiden kirjoittaminen on dialogista toimintaa, jossa kirjoittaja ja lukija jatkuvasti ottavat toisensa huomioon ja vaikuttavat toisiinsa. Mitä kirjoittaja kirjoittaa, mutta myös miten hän sen kirjoittaa, määräytyy mitä suurimmassa määrin niistä reaktioista, joita hän ennakoi kirjeensä herättävän vastaanottajassa. (Bakhtin 2002, 95; Bakhtin 2003, 204-205.) Kotiväkeä ei haluttu turhaan huolestuttaa tai järkyttää, mikä osin selittää, miksi kirjeet eivät yleensä sisällä yksityiskohtaisia kuvauksia rintamasta kuoleman tai tuhon maisemana. Miehillä oli kuitenkin välillä tarvetta purkaa tunteitaan ja kertoa myös raskaista kokemuksistaan, ja siksi maiseman tuhoista, vaaroista ja rasittavuudesta ei täysin vaiettu. Tämän lisäksi miehet olivat tietoisia siitä, että kotiväki halusi olla heidän tukenaan aina, kun he olivat tuen tarpeessa. Kotona haluttiin myös mielellään lukea miesten kokemuksista ja vaikutelmista. Tällä tavoin kotiväki ja muut läheiset saivat käsityksen heille vieraasta ja kaukaisesta maisemasta rintamalla ja pääsivät ainakin jossain määrin osallisiksi miesten elämästä toisaalla pitkän erossaolon aikana.

Arvioidessaan, miten heidän kirjeensä otettaisiin kotona vastaan, miehet joutuivat todennäköisesti tasapainoilemaan kertomisen ja vaikenemisen välillä. Vaikka kirjeet rintamalta sisälsivät mainintoja sodan väkivaltaisesta maisemasta ja kurjista ja vaarallisista oloista, painopiste oli kaikessa sellaisessa, mikä oli kotiväelle lähempänä totuttua ja tuttua. Tavallisimmin kirjeissä luotiin illuusio turvallisuudesta, normaaliudesta ja jatkuvuudesta, ja siitä, että elämä rintamalla ei poikennut kovinkaan paljon arjesta kotona. Pitkän erossaolon aikana, jolloin etäisyys osapuolten välillä uhkasi kasvaa, oli kirjeissä tärkeää painottaa kodin ja rintaman välisiä kosketuspintoja. Viime kädessä maisema rintamalla koettiin aina vieraana suhteessa omaan kotiin, kotiseutuun ja kotimaahan, jonne jatkuvasti ikävöitiin ja jonne haluttiin palata.

\section{Tutkimusaineisto}

\section{Arkistolähteet}

Åbo Akademis bibliotek (ÅAB), Handskriftssamlingarna

Kirjekokoelma: Björkman, suku

Kirjekokoelma: Enroth, Curt ja Martha

Kirjekokoelma: Sax

Kirjekokoelma: Segerstråle, Ulf 


\section{Painetut lähteet}

Rakennusopas kenttämajoitusta varten 1943. Helsinki: Kustannusosakeyhtiö Otavan kirjapaino.

\section{Kirjallisuus}

Alsmark, Gunnar 1997: Inledning. - Alsmark, Gunnar (red.), Skjorta eller själ? Kulturella identiteter i tid och rum. Lund: Studentlitteratur. 9-20.

Ampuja, Outi 2001: Ääni ja melu modernissa sodankäynnissä. - Laakkonen, Simo \& Timo Vuorisalo (toim.), Sodan ekologia. Sodankäynnin ympäristöhistoriaa. Historiallinen Arkisto 125. Helsinki: Suomalaisen Kirjallisuuden Seura. 304-339.

Bakhtin, Mikhail 2003: Problems of Dostoevsky's Poetics. - Emerson, Caryl (ed. \& transl.), Theory and History of Literature, Volume 8. Minneapolis: University of Minnesota Press [1984].

Bakhtin, Mikhail 2002: Speech Genres \& Other Late Essays. - Emerson Caryl \& Michael Holquist (eds.). Austin: University of Texas Press [1986].

Colville, Quintin 2009: Corporate Domesticity and Idealised Masculinity. Royal Naval Officers and their Shipboard Homes, 1918-39. - Gender \& History, 21(3): 499-519.

Deleuze, Gilles \& Félix, Guattari 2004: A Thousand Plateaus. Capitalism and Schitzophrenia. Translation and Foreword by Brian Massumi. London: Contiuum [1988].

Fritz, Stephen G. 1995: Frontsoldaten. The German Soldier in World War II. Kentucky: University Press of Kentucky.

Greverus, Ina-Maria 1972: Der territoriale Mensch. Ein literaturanthropologischer Versuch zum Heimatphänomen. Frankfurt: Athenäum.

Hagelstam, Sonja 2014: Röster från kriget. En etnologisk studie av brevdialoger mellan frontsoldater och deras familjer 1941-1944. Doktorsavhandling. Åbo: Åbo Akademi.

Hagelstam, Sonja 2011: Rakas sotilaani! Kirjeiden kirjoittaminen jatkosodan poikkeusoloissa. - Leskelä-Kärki, Maarit ym. (toim), Kirjeet ja historiantutkimus. Helsinki: Suomalaisen Kirjallisuuden Seura. 299-328.

Hagelstam, Sonja \& Ilari Taskinen 2015: Hiljaisuuden myytit. Postisensuuri, vaikeneminen ja etulinjan kokemukset sota-ajan kirjeissä. - Tikka, Marko ym. (toim.), Kirjeitä sodasta. Kirjoittamisen tavat ja merkitykset kriisiaikoina. Tampere: Postimuseo \& Tampereen Historiallinen Seura. 44-59.

Hakamies, Pekka 2012: Karjala venäläisin silmin. - Fingerroos, Outi \& Maunu Häyrynen (toim.), Takaisin Karjalaan. Helsinki: Suomalaisen Kirjallisuuden Seura. 75-104.

Helamaa, Erkki 1983: 40-luku. Korsujen ja jälleenrakentamisen vuosikymmen. Helsinki \& Jyväskylä: Suomen rakennustaiteen museo \& Alvar Aalto museo.

Helphand, Kenneth I. 2006: Defiant Gardens. Making Gardens in Wartime. San Antonio: Trinity University Press.

Hietanen, Silvo 1990: Karjala nousee tuhkasta. - Hietanen, Silvo (päätoim.), Kansakunta sodassa 2: Vyö kireällä. Valtion painatuskeskus \& Opetusministeriö: Helsinki. 152-169.

Hynes, Samuel 1998: The Soldiers' Tale. Bearing Witness to Modern War. New York: Penguin Books. [1997]. 
Häyrynen, Maunu 2004: "Maisemantutkijan kotiseutu" - Granö, Päivi ym. (toim.), Koti. Kaiho, paikka, muutos. Kulttuurituotannon ja maisemantutkimuksen laitoksen julkaisuja IV. Pori: Turun yliopisto. 55-68.

Jürgenson, Aivar 2015: Between Landscapes. Migration as Rupture and its Expression in the Landscape. - Sooväli-Sepping, Helen ym. (eds.), Ruptured Landscapes. Landscape, Identity and Social Change. Landscape Series 19. Dordrecht: Springer Science+Business Media. 111-129.

Kirves, Jenni 2008: "Päivittäinen myrkkyannoksemme" - sensuuria ja propagandaa jatkosodassa. - Näre, Sari \& Jenni Kirves (toim.), Ruma sota. Talvi- ja jatkosodan vaiettu historia. Helsinki: Johnny Kniga. 13-61.

Kivimäki, Ville 2014: Rintamamiesten Suur-Suomi. Odotukset, kokemukset ja tunteet jatkosodassa. - Näre, Sari \& Jenni Kirves (toim.), Luvattu maa. Suur-Suomen unelma ja unohdus. Helsinki: Johnny Kniga. 259-319.

Knoch, Peter 1989: Kriegsalltag. - Knoch, Peter (Hrsg.), Kriegsalltag. Die Rekonstruktion des Kriegsalltags als Aufgabe der historischen Forschung und der Friedenserziehung. Stuttgart: J. B. Metzlersche Verlagsbuchhandlung. 222-251.

Kosonen, Katariina 2012: Barbarian ja sivistyksen rajalla - Suomi ja Karjala lännen etuvartiona. - Fingerroos, Outi \& Maunu Häyrynen (toim.), Takaisin Karjalaan. Helsinki: Suomalaisen Kirjallisuuden Seura. 193-195.

Laakkonen, Simo 2007a: Johdanto sodan ekologiaan. - Laakkonen, Simo \& Timo Vuorisalo (toim.), Sodan ekologia. Sodankäynnin ympäristöhistoriaa. Historiallinen Arkisto 125. Helsinki: Suomalaisen Kirjallisuuden Seura. 15-34.

Laakkonen, Simo 2007b: Sota, ympäristö ja yhteiskunta. - Laakkonen, Simo \& Timo Vuorisalo (toim.), Sodan ekologia. Sodankäynnin ympäristöhistoriaa. Historiallinen Arkisto 125. Helsinki: Suomalaisen Kirjallisuuden Seura. 35-69.

Lappalainen, Matti 1990: Sodan ratkaisu siirtyy - asemasodan armeija. - Hietanen, Silvo (päätoim.), Kansakunta sodassa 2: Vyö kireällä. Valtion painatuskeskus \& Opetusministeriö: Helsinki. 22-45.

Leed, Eric J. 2009: No Man's Land. Combat \& Identity in World War I. London: Cambridge University Press (1979).

Luostarinen, Heikki 1986: Perivihollinen. Suomen oikeistolehdistön Neuvostoliittoa koskeva viholliskuva sodassa 1941-44: tausta ja sisältö. Tampere: Vastapaino.

Mustanoja, Liisa (toim.) 2017: Arjen sirpaleita ja suuria tunteita. Kirjeet sodan sanoittajina ja ihmissuhteiden ylläpitäjinä 1939-1944. Tampere: Tampereen yliopisto. [online] < http:// urn.fi/URN:ISBN:978-952-03-0527-7. > [19.4.2018.]

Pehkonen, Erkka 2013: "Poikasi täältä jostakin". Narratiiviset resurssit, diskurssit ja luovuus kirjoittaen kerrotuissa identiteeteissä jatkosodan aikaisissa kirjeissä. Jyväskylä: Jyväskylän yliopisto.

Petrisalo, Katriina 2004: Koti ja matkailu. Kodista pois - ja takaisin kotiin. - Granö, Päivi ym. (toim.), Koti. Kaiho, paikka, muutos. Kulttuurituotannon ja maisemantutkimuksen laitoksen julkaisuja IV. Pori: Turun yliopisto. 69-78.

Pöysä, Jyrki 2015: Lähiluvun tieto. Näkökulmia kirjoitetun muistelukerronnan tutkimukseen. Kultaneito XVII. Joensuu: Suomen Kansantietouden Tutkijain Seura. 
Sallinen, Susanna 2004: Koti-ikävä ja nostalgia arjen kokemuksena. - Granö, Päivi ym. (toim.), Koti. Kaiho, paikka, muutos. Kulttuurituotannon ja maisemantutkimuksen laitoksen julkaisuja IV. Pori: Turun yliopisto. 79-102.

Sevänen, Erkki 1997: Ensimmäisen tasavallan poliittinen tilanne ja kirjallisen älymystön toimintastrategiat. - Karkama, Pertti \& Hanne Koivisto (toim.), Älymystön jäljillä. Kirjoituksia suomalaisesta sivistyneistöstä ja älymystöstä. Tietolipas 151. Helsinki: Suomalaisen Kirjallisuuden Seura. 33-63.

Tikka, Marko ym. (toim.) 2015: Kirjeitä sodasta. Kirjoittamisen tavat ja merkitykset kriisiaikoina. Tampere: Postimuseo \& Tampereen Historiallinen Seura.

Woodward, Rachel 1998: 'It's a Man's Life': soldiers, masculinity and the countryside. Gender, Place and Culture 5(3): 277-300.

Woodward, Rachel 2004: Military Geographies. Malden: Blackwell Publishing.

Ziemann, Benjamin 2007: War experiences in rural Germany 1914-1923. Translated by Alex Skinner. Oxford: Berg.

FT Sonja Hagelstam on etnologian tutkija Åbo Akademissa. 